\title{
$D R=0630-0$
}

DOE/OR/03054-51

(DE85001489)

ASSESSMENT OF FEEDABILITY OF KERR-McGEE ASH CONCENTRATE

By

S. F. Moujaes

September 1983

Work Performed Under Contract No. AC05-78OR03054

Jenike \& Johanson, Inc.

North Billerica, Massachusetts

and

International Coal Refining Company

Allentown, Pennsylvania

Technical Information Center

Office of Scientific and Technical Information United States Department of Energy 


\section{DISCLAIMER}

This report was prepared as an account of work sponsored by an agency of the United States Government. Neither the United States Government nor any agency Thereof, nor any of their employees, makes any warranty, express or implied, or assumes any legal liability or responsibility for the accuracy, completeness, or usefulness of any information, apparatus, product, or process disclosed, or represents that its use would not infringe privately owned rights. Reference herein to any specific commercial product, process, or service by trade name, trademark, manufacturer, or otherwise does not necessarily constitute or imply its endorsement, recommendation, or favoring by the United States Government or any agency thereof. The views and opinions of authors expressed herein do not necessarily state or reflect those of the United States Government or any agency thereof. 


\section{DISCLAIMER}

Portions of this document may be illegible in electronic image products. Images are produced from the best available original document. 


\section{DISCLAIMER}

This report was prepared as an account of work sponsored by an agency of the United States Government. Neither the United States Government nor any agency thereof, nor any of their employees, makes any warranty, express or implied, or assumes any legal liability or responsibility for the accuracy, completeness, or uscfulness of any information, apparatus, product, or process disclosed, or represents that its use would not infringe privately owned rights. Reference herein to any specific commercial product, process, or service by trade name, trademark, manufacturer, or otherwise does not necessarily constitute or imply its endorsement, recommendation, or favoring by the United States Government or any agency thereof. The views and opinions of authors expressed herein do not necessarily state or reflect those of the United States Government or any agency thereof.

This report has been reproduced directly from the best available copy.

Available from the National Technical Information Service, U. S. Department of Commerce, Springfield, Virginia 22161.

Price: Printed Copy A04

Microfiche A01

Codes are used for pricing all publications. The code is determined by the number of pages in the publication. Information pertaining to the pricing codes can be found in the current issues of the following publications, which are generally available in most libraries: Energy Research Abstracts (ERA): Government Reports Announcements and Index (GRA and I); Scientific and Technical Abstract Reports (STAR); and publication NTIS-PR-360 available from NTIS at the above address. 


\title{
ASSESSMENT OF FEEDABILITY OF
}

\section{KERR-MCGEE ASH CONCENTRATE}

\author{
Prepared by \\ Jenike \& Johanson, Inc. \\ and \\ S. F. Moujaes \\ INTERNATIONAL COAL REFINING COMPANY \\ P.0. Box 2752 \\ Allentown, Pennsylvania 18001 \\ for the \\ UNITED STATES DEPARTMENT OF ENERGY \\ Office of Solvent-Refined Coal Products \\ under Contract. DE-ACO5-78-0R0-3054
}




\section{ABSTRACT}

Tests were performed to determine the feasibility of conveying KerrMcGee ash concentrate from storage bins through the screw feeder to the Gesellschaft für Kohle-Technologie (GKT) gasifier. A study comparing flow characteristics of coal, for which the GKT system was designed, and Kerr-McGee ash concentrate (KMAC) showed that properties were similar, although KMAC had a lower bulk density. A computer simulation based on these properties was then applied to the conveying system. Results showed that KMAC flow will be unstable for almost all the KMAC samples studied when the gradients in gas and solid contact pressure in the convergent outlet of the screw feeder are very large, and when the scale factor is relatively high, i.e., greater than the critical value of 460 . However, use of larger bins coupled with operation of the screw feeder at a slower rpm should result in stable operation and satisfy the flow requirements of the process design.

GKT concluded that while improvements can be made to boost throughput and increase stability, serious consideration should be given to an alternate pneumatic conveying system to the gasifier. 


\section{IABLE OF CONTENTS}

\section{Page}

ABSTRACT

EXECUTIVE SUMMARY

INTRODUCTION

MATERIAL FLOW PROPERTIES

SOLIDS FLOW BEHAVIOR IN THE SYSTEM

MATHEMATICAI ANAIYSTS

DISCUSSION

CONCLUSIONS

GKT'S REVIEW OF JJI SCREW FEEDER TEST REPORT 12

LITERATURE CITED 13

APPENDICES

Appendix A - Standard Test Report: Coal Flow Properties A1

Appendix B - Standard Test Report: KMAC Flow Properties B1

Appendix C - Selection of Bin and Feeder $\quad .1$

Appendix D - Recommendations for Future Work $\quad 01$

List of Tables

1 - Summary of Material Flow Properties $\quad 15$

2 - Samples of Simulation Results 16

3 - Scale Parameter for Feed System 1.7

4 - Physical Properties of Test Materials 18

List of rigures

1 - Elastic Analysis of Convergence 19

2 - Example of Solid and Gas Pressure Distributions for Coal 18420

3. - Example of Solid and Gas Pressure Distributions for KMAC $212 \quad 21$

4 - Example of Solid and Gas Pressure Distributions for KMAC 22 212 at Low Solids Flow Rate 


\section{EXECUTIVE SUMMARY}

This report summarizes work performed by Jenike \& Johanson, Inc. (JJI) under ICRC Subcontract No. 01-13092-00, to assess the feedability of ash concentrate from the Kerr-McGee critical solvent deashing unit through the storage bins and screw feeder to the Gesellschaft für KohleTechnologie (GKT) gasifier. Because the technology was designed for coal, ICRC was uncertain whether it would work reliably with the KerrMcGee ash concentrate (KMAC).

The work done by JJI was divided into two sections:

1. Flow properties of two pulverized coal and four KMAC samples were studied. This study determined solid density, average particle size, volatiles content, compressibility, permeability material flow factor, and the kinematic angle of friction between the solid and a wall supporting it.

2. Given GKT's proprietary bin design and the best estimate of CKT's proprietary design for the screw feeder to the gasifier, a computer simulation was developed using a proprietary JJI code to model the flow behavior of these samples. This part of the study attempted to predict those conditions that would result in unstable, marginally stable, and fairly stable flow of the KMAC powder.

The first study showed that, in general, the KMAC samples had lower gas permeabilities, bulk densities, and ultimate densities than the coal samples. Because such material properties are coupled very strongly with flow characteristics, KMAC may be more difficult to convey through the system.

GKT had indicated that particularly dry coa ${ }^{*}$ can cause unstable discharge (or "spitting") from the cunverging section, and excessively moist coal* can "plug" or overload the screw. Thus, both coal. and KMAC samples having moisture contents at either extreme were tested. Over

*Means out of the range specified by GKT. 
this range of moisture, flow properties for both KMAC and coal did not vary appreciably, although KMAC samples had a low bulk density. Overall, the tests indicated that the system is sensitive to slight changes in flow properties, necessitating a more detailed study.

Because the coal and KMAC samples were expected to be in finepowder form, the second study, a two-phase flow study, was conducted to better understand the behavior of these materials in the storage bin, the screw feeder, and the converging section that leads to the gasifier. A Illathematical analysis based on a proprietary JJI two-phase (solid/ tluid) Hlow romputier program was employed. Sulle. disumptions had to be made in this study, primarily because information on GKT's screw feeder geumetry was proprietary and unavailable. The results were not unique solutions, but a range of solutions, i.e., allowing for more than one screw configuration and set of operating conditions with which the flow of KMAC will be stable.

This second study has shown the following:

- A low average axial solids contact pressure along the height of the storage bin can lead to instabilities in the solids flow.

- The lower the scale factor, i.e., the ratio of average solids velocity to reference permeability, the better the chance for interstitial gas to redistribute itself. This would also lead to more stable operation.

- Lower flow rates and higher volatile contents produce better operation.

- Increasing cohesion increases flow stability, which can also be modelled, but ways of achieving this are currently unknown.

- A combination of high axial solids contact pressure and cohesion causes the screw feeder system to nverload, or plug. This suggests that higher flow rates in the screw would create a lower solids axial pressure and less possibility of plugging. On the other hand, higher flow rates would cause objectionable stability problems. This suggests that a good design without plugging or instability problems can be arhieved only by finding the optimum combination of system geometry, axial solids contact pressure, and flow rates. 
- Finally, based on the design provided by GKT to convey the KMAC to the gasifier and the flow properties and flow conditions of the different KMAC samples, the simulation indicates that the conveyability of KMAC in a steady-state manner is uncertain. However, the fact that JJI did not know the geometry of the screw feeder must be kept in mind. The computer simulation showed that none of the KMAC samples met the criterion for stable flow without "spitting." However, use of larger bins and operation of the screw feeder at a slower rpm should result in stable operation and satisfy the flow requirements of the process design.

GKT reviewed this report and concluded that improvements can be made to the system to boost throughput and increase stability. However, GKT suggested that serious consideration be given to an alternate conveying system to the gasifier, developed by GKT. The new pneumatic feeding system is available for commercial application and could be integrated into the SRC-I plant design.

\section{INTRODUCTION}

ICRC is considering a GKT system for feeding KMAC into a medium-Btu gasifier in the SRC-I Demonstration Plant. The basic system consists of:

- a continuous-feed, agitator-type blender that adds moisture to the feedstock to control its handleabllity;

- a material-receiving bin consisting of a tall cylinder, a converging cone, and a transition hopper converging to a rectangular outlet;

- dual discharge screws;

- a converging section on each screw with a specified reduction in cross-sectional area to prevent back flow of the steam/oxygen from the gasifier into the bin.

GKT indicated that "spitting" (unstable discharge) from the con-. verging section occurs with pulverized coals when they are particularly dry or fine being out. of the range of grain size and moisture content specified by GKT. On the other hand, moisture contents higher than that specified tend to cause "plugging" or overloading of the screw. 
ICRC must know whether the system will work reliably with KMAC. Since the system design is largely empirical and KMAC has not been handled before, JJI was asked to utilize these limited data to predict the system's performance with KMAC.

\section{MATERIAL FLOW PROPERTIES}

Two samples of pulverized coal and four samples of KMAC were tested to determine their flow properties. The two coal samples chosen from the five provided by GKT were: 184, which is the finest bituminous coal, and 183, which is the finest lignite. Tluse were selected since finer materials are generally more difficult to handle because of their lower gas permeability. All of the KMAC samples from ICRC were tested, al though the two finest (211C and 212) were subjected to a more thorough examination. Most of the test.s were run at $72^{\circ} \mathrm{F}$, since it was found that the material flow properties are not significantly affected by temperatures between 72 and $176^{\circ} \mathrm{F}$.

The material flow properties are described in the attached Standard Test Reports, Appendix A for the coals and Appendix B for the KMACs, and summarized in Table 1.

In general, the KMACs have lower gas permeabilities (represented by KO), bulk densities (represented by GAMMAmin), and ultimate densities (CAPGAMMA) than the pulverizen soals. This indirates that handling problems are more likely to occur with the fine KMACs.

The properties of the two GKT coals (183 and 184) were determined at the extremes of volatile (moisture) content, at which spitting and plugging problems were said to occur. These test results were to provide a basis tor determining the range of acceptable flow properties. Unfortunately, each roal's flnw properties shange vory littlc with moisture content..

KMACs $211 C$ and 212 were also tested over a wide range of volatile contents for direct comparison with the coals' properties to assess KMAC handleability. These tests indicate that, except for the low hulk density of the KMACs, the other flow properties measured span ranges similar to those of the coals.

The general conclusions from these test results are that the system is sensitive to slight changes in flow properties and that a detailed analysis of the system must be done. 
SOLIDS FLOW BEHAVIOR IN THE SYSTEM

All of the coals and KMACs tested are fine powders and consequently exhibit significant two-phase flow effects from the movement, however slight, of interstitial gas as the powders are compressed or expand. The following is a description of the various flow conditions that can occur in the system, depending on solids flow rate and material flow properties.

\section{Flow in the Bin}

In the mass flow bin feeding the screws, the material can take three flow-rate-dependent modes. The first mode occurs at flow rates below the conservative limiting conditions tabulated in the standard Test Reports, which assume that the gas pressure at the bin top and bottom are equal. This mode is characterized by the steady gravity flow of partially deaerated material controlled by the feeder. The limiting steady-state condition occurs when compaction in the cylinder forces too much gas out through the material top surface, causing a slight vacuum to form as the material expands while flowing through the converging portion of the bin. The result is a gas counterflow through the bin outlet that forces the solids contact pressure, SIGMA, to drop to zero, and limits the steady solids flow rate.

The second mode of flow occurs at flow rates somewhat greater than the limiting rate. A steady rate from the bin can be achieved only by the use of a gas permeation or injection system at an intermediate point in the bin to replace the lost gas. Without this gas addition, an erratic, partially fluidized powder flows from the bin, and can be controlled by some compacting screw arrangements.

The third mode occurs when the flow rate is too high to allow much, if any, gas to escape from the material voids. In this extreme, the material may be completely fluidized and flood or flush through the outlet unless the feeder can control fluidized solids.

(See Appendix $C$ for a more detailed description of bin geometry and terminology. ) 


\section{Flow in the Screw}

The purpose of the screw in conjunction with the convergence is to compact material to provide a gas seal from the higher gas pressure downstream of the hopper, and to feed the coal or ash uniformly at a controlled rate to the gasifier. The boundary conditions imposed by the hopper define the solids density, amount of entrained gas, and gas pressure at the entrance to the screw. The screw must have sufficient length and power to transport and prepare this solid for entrance to the converging section, which imposes a back pressure on the screw to effect lie yas sedl. If lle screw is lou shurl, Il will have difficully gerle erating the necessary back pressure without significantly reducing its volumetric efficiency, thus reducing the throughput of the system. If the screw is too long, the torque and power required to achieve a satisfactory seal may exceed the mechanical design limits of the screw. Unfortunately, the screw design requirements change as a function of material properties and feed rate; consequently, a given screw configuration will work only over a restricted range of flow rates and material properties. The restrictions for this particular system are described in the Conclusions section.

A general analysis of sealing screws shows that the minimum SIGMA (axial solids contact pressure) occurs in the portion of the screw under the feed hopper. The maximum SIGMn occurs at the interface of the screw and the converging section.

\section{Flow in the Convergence}

The converging section is the heart of the sealing system. If the convergence is too slight, the seal will be ineffective, and gas will leak through the screw. When this gas counter flow reaches the hopper uullel, a mumenlary bridye will form, and the screw will empty com= pletely. A surge of fluidized powder will likely flush into the screw, and a pulsating flow from the screw will occur. If the powder is somewhat cohesive, the solids flow from the hopper may stop completely. If the convergence is too large, the back pressure on the screw will be excessive, and overload it. 
In general, the degree of convergence required is a function of the material flow properties, the inlet conditions to the screw, the screw design, and the solids flow rate. For example, if the solid is somewhat fluidized at the converging section inlet, a large convergence is required. If the solid is relatively free of gas and is virtually incompressible, then a small convergence is required. A large convergence in this case will likely cause overloading of the screw. If the solid is cohesive, particularly if cohesion increases significantly with increasing SIGMA, the converging section is likely to plug unless the convergence is minimal.

The most critical part of the system for stability is the con-. verging section outlet. At this surface, the dimensionless gas pressure gradient ( $d P / d x) / G A M M A$ opposing solids flow must balance the dimensionless solids contact pressure gradient (dSIGMA/dx)/GAMMA. Unfortunately, the position of the solid surface at the outlet will change from time to time, especially with slightly cohesive solids in which chunks may dislodge from the end surface, leaving voids. If these voids produce an instability, a pulsating flow will result. This can be predicted mathematically by calculating the changes in ( $\mathrm{dP} / \mathrm{dx}$ )/GAMMA and (dSIGMA/ $d x$ )/GAMMA near the outlet. If there is a significant change in (dSIGMA/ $d x)$ /GAMMA in the region of the converging section outlet, an instability in flow is expected.

\section{MATHEMATICAL ANALYSIS}

Basis of Analysis

The mathematical analysis is based on a JJI proprietary two-phase (solids/fluid) flow computer program. The basic assumptions for calculation are outlined by Johanson (1979). Due to the unknown geometry of the screw section, JJI has analyzed only the bin and the converging section. The major assumptions are:

- The walls of the bin are smooth and steep enough for mass flow, i.e., for material to slide along them. This is essential to the steady-state operation of the system with coal or KMAC. 
- The screw is designed in whatever way necessary to provide continuity of gas, solids, solids compaction, and gas pressure gradient to match the outlet of the hopper with the converging section inlet.

- The converging section can be represented by a mass flow cone with GKT proprietary geometry. Variations in absolute geometry should not affect the solution trends unless the screw flights extend into the convergence.

- The stress field in the convergence is plastic. An elastic field (uniform material velocity) would generate extremely large solids contact and gas pressures in the convergence, which are incompatible with the zero solids and fixed gas pressures at the converging section outlet. This analysis is shown in Figure 1 , in which the bulk solid has been reduced to its equivalent constituents of solid and gas.

- The existing GKT coal systems are identical to the proposed KMAC system, except for material flow rates due to the differing quality of feedstocks.

As a result of the unspecified screw, no unique solution to the problem is defined, but families of solutions are calculated. Each solution within a family represents a possible screw configuration and operating condition. In general, the wider the range of these solutions, the more screw configurations and operating conditions are allowed.

Results of Computer Simulation

Results of some of the simulations are shown in Table 2. The variables are: SIGMA - the axial solids contact pressure, $P$ - the gas pressure, and $(d P / d x) / G A M M A$ - the dimensionless gas pressure gradient that affect.s the flow rate of gas through the surface. (Values of $P$ and SIGMA were deleted from various sections of Table 2 because of their proprietary nature.) The dimensionless solids contact pressure gradient, (dSIGMA/dx)/GAMMA, is calculated 0.25 in. from the converging section outlet. Note that most of these simulations were performed with room temperature permeability. Reducing permeability by about $17 \%$ to account for the increased temperature will not change the solution trends. 
In general, measured variations in GAMMAmin, BETA (compressibility), KO (permeability constant), and PHI-PRIME (kinematic angle of friction between a solid and a wall) change the boundary value magnitudes within about $10 \%$, but do not significantly affect the general solution trends shown in Table 2.

Based on past experiences with two-phase flow computations and the limited computer results for this specific problem, it appears that the dimensionless scale factor, Vs/KO - the average solids velocity at the assumed converging section outlet divided by $K 0$, provides a means of comparing different flow conditions. This scale factor is corrected to $80^{\circ} \mathrm{C}$ and tabulated in Table 3 for a variety of materials and possible flow conditions.

\section{DISCUSSION}

Instabilities in Solids Flow

The instabilities in solids flow (spitting) are caused by rapid changes in solids contact and gas pressures at the converging section outlet. As an example, consider the mathematical solution of a known stable case of coal 184 shown in Figure 2. SIGMA in the bin is high enough and typical for a mass flow bin so that there is no tendency for fluidization. In addition, SIGMA has a smooth continuous decrease in the converging section. In the region of the converging section outlet where instabilities start, the solids and gas pressure gradients are essentially constant. This is also evident in Table 2 if the magnitude of $(d P / d x) /$ GAMMA is compared with ( $d S I G M A / d x) / G A M M A$ in the last column for coal 184.

For comparison, consider the example solution shown in Figure 3 for KMAC 212. SIGMA in the hopper is very sma 11, indicating fluidization or near-fluidization conditions. At the converging section outlet, the sudden jump in SIGMA and $P$ indicates an instability. In lable 2, KMAC 212 shows this instability in terms of the computed ( $d P / d x) / G A M M A$ and (dSIGMA/dx)/GAMMA for all of the solutions, with the possible exception of the 1.5-ton-per-hour (tph) feed rate, which is depicted in Figure 4. 
Correlation with Scale Factors. The instabilities occur because of the inability of the interstitial gas in the KMAC or coal to redistribute quickly, and thus provide consistent pressure gradients at the converging section outlet. The ability of gas to redistribute is reflected in the ratio of average solids velocity to the reference permeability, Vs/KO, since the gas velocity is proportional to KO and the gas pressure gradient. If this scale factor (SF) is low, the gas can redistribute more easily; if it is high, redistribution is more difficult. With coal 184 at 1.1 wt \% volatiles content as a limiting case of instability, it appear's rruil Table 3 that an st of 460 is critical; therefore, all of the KMACs at the required rate of $7.6 \mathrm{tph}$, except 162C, will have serious instabilities. KMAC $162 \mathrm{C}$ was produced by an unusual set of operating conditions, and is not expected to be the normal feed.

Effects of Flow Rate and Volatiles Content on Stability. Lower flow rates and high volatiles contents tend to produce more stable conditions. For example, with SF equal to 460 as the upper limit for stability and the fact that SF is directly proportional to flow rate, Q, for any given material, Table 3 indicates that KMAC 212 at 1.5 tph and 1.7 wt \% volatiles content is likely to be unstable, but that if the rate were slowed to 1.2 tph or less, stability would be achieved. The table also suggests that at $2.7 \mathrm{wt} \%$ volatiles content, stability can be achieved at about 2.0 tph or less.

Stability with Cohesive Effects. It is possible that flow stability can be improved by increasing KMAC's cohesion. The cohesion could change the stress calculation so that there is no need for SIGMA to be zero at the converging section outlet, thereby eliminating the rapid change in solids and gas pressure gradients that cause instability. Unfortunately, the control of material cohesion is uncertain, and it is not recommended to design a system dependent on it.

Conditions Causing Screw Plugging. The calculated results plotted in Figure 2 for a known stable condition indicate that the screw has to generate a high SIGMA at the converging section inlet. This pressure is consistently high for the range of solutions developed, and, in combination with high cohesion, is the cause of screw overloading or plug- 
ging. For example, the solution shown in Figure 2 has SIGMA equal to zero at the converging section outlet. If the coal or KMAC has sufficient cohesion (as indicated by a low value of $\mathrm{ff}$ in Table 1), SIGMA at the outlet could increase significantly, which would cause a corresponding increase in the required SIGMA at the converging section inlet, thus resulting in screw plugging.

If the screw is operating with a higher flow rate, SIGMA at the converging section inlet would be lower, and plugging would be less likely. It appears that any plugging criteria must contain a combination of SF that involves solids feed rate and $f f$ that represents the material's cohesive properties. Consider that coal 184 at 2.4 wt \% volatiles content represents a plugging condition. This suggests that ff equal to 3.8 and SF equal to 372 represents a plugging condition. For equivalent scale factors, ff equal to 3.8 represents a limit on the flow factor below which plugging is likely to occur. Thus, KMAC 212 at 7.0 wt $\%$ volatiles content with the system operating at $1.5 \mathrm{tph}$ is likely to cause plugging. However, if the system is operated at a higher flow rate, plugging may not occur. Unfortunately, the system may be unstable at this higher rate, especially if the volatiles content drops to $1.7 \%$.

\section{CONCLUSIONS}

- In general, it appears that the systems currently in operation handling coal are sensitive to slight changes in coal flow properties, but that the coals being handled have fairly consistent flow properties, even with the addition of water. The KMACs tested seem to have a much wider variation of properties from lot to lot than the coal; consequently, JJI expects more problems achieving a suitable system design to handle the raluge or KMACs tested than to handle the coals.

- It appears that the system currently being used for the coal will not work for the typical KMACs unless the required feed rate is significantly reduced.

- It is possihle to design a system to handle the KMAC at the required rates of about 5.3 to $7.6 \mathrm{tph}$. Such a system would likely 
require a larger surge hopper to deaerate the KMAC and larger screws turning at a lower rpm than those currently used for coal at $5.6 \mathrm{tph}$. The design parameters of the system could be established by use of JJI's two-phase-flow computer program.

\section{GKT'S REVIEW OF JJI SCREW FEEDER TEST REPORT}

\section{Background Description}

GKT was authorized under ICRC Contract No. 01-11002 Amendment No. 11 to review the test report prepared by Jenike \& Johanson, Inc. (JJI) on KMAC feedability in the screw feeder. This was one of the closeout activities defined in Task 104 of the Activities Completion Plan for the SRC-I Demonstration Plant. For further information, refer to DOE/OR/03054-46, GKT Unlimited Rights Data, GKT Review and Engineering Report, Sections 2 and 5.

\section{GKT's Comments on JJI Report}

GKT's comments can be summarized as follows:

- The design of the screw feeder for KMAC feeding was based on the assumption that KMAC will flow in a manner similar to that of coal. To prove this assumption, the design confirmation test was proposed, but was postponed due to high cost and a change in project direction.

- GKT did not question the theoretical basis developed by JJI for computer analysis of the screw feeder.

- In JJI's report under "Flow in the Bin," three modes of mass flow pattern in the bin were defined. The first mode occurs at a flow rate below the conservative limiting conditions when the qas pressures at the bin top and bottom are equal. The second mode of flow occurs at a flow rate somewhat greater than the limiting rate. The third mode occurs when the flow rate is too high to allow gas to escape from the material voids. JJI stated that a steady flow rate from the bin can be achieved only by the use of a gas injection system at an intermediate point in the bin to replace the lost gas when the second mode occurs. However, GKT stated that the continuous injection of gas into the bin has been shown to be unnecessary based on experience. GKT also stated 
that the volume fluctuations occurring at the outlet of the bin can be compensated for by the compacting characteristics of the screw.

- In JJI's report under "Flow in the Screw," JJI stated that the requirements of screw design change as a function of material properties and feed rate. A given screw configuration will work only over a restricted range of flow rates and material properties. GKT agreed, and commented that GKT's screw design is equipped with compacting adjustment capability to provide adjustment of flow rate and compensation for conveyance characteristics for different feedstocks.

- GKT did not directly comment on the conclusions drawn by JJI on expected problems associated wtih screw feeding KMAC material. GKT only stated that improvements can be made in GKT's screw design.

- GKT recommended that the pneumatic feeding system be incorporated (to replace the screw feeder) in the SRC-I Demonstration Plant.

\section{ICRC's Viewpoint}

ICRC believes that the expected problems pointed out by JJI could occur if GKT's screw feeder is used for feeding KMAC material. ICRC also believes that some flexibility exists in GKT's screw design with adjustment of the screw plug. However, the technical uncertainty of GKT's screw feeding KMAC material remains unresolved. It is impossible to scale up results from the small screw feeder tests according to GKT. Commercial-scale screw testing is the only way to affirm whether GKT's screw feeder would perform satisfactorily in feeding KMAC material.

ICRC agrees that the pneumatic feeding system is less restricted, and depends much less upon the physical properties of feedstocks. A confirmation lab-scale test can be carried out with much less cost to provide design information. It is strongly recommended that the pneumatic feeding system be considered for incorporation into the gasification unit if the SRC-I Project moves to the next detailed design and construction phase.

\section{LITERATURE CITED}

Johanson, J. R. 1978a. Know your material--how to predict and lise the properties of bulk solids. Chem. Eng. Deskbook Issue. October 30: $9-17$. 
1978b. Design for flexibility in storage and reclaim. Chem. Eng. Deskbook Issue. October 30:19-26.

- 1979. Two-phase-flow effects in solids processing and handling. Chem. Eng. January 1:77-86. 
Table 1

Summary of Material Flow Properties

\begin{tabular}{|c|c|c|c|c|c|c|c|c|}
\hline Sample & $\begin{array}{l}\text { Solid density } \\
\text { [CAPGAM (pcf)] }\end{array}$ & $\begin{array}{c}\text { Average } \\
\text { particle } \\
\text { size } \\
\text { (micron) }\end{array}$ & $\begin{array}{l}\text { Volatile } \\
\text { content } \\
(\%)\end{array}$ & 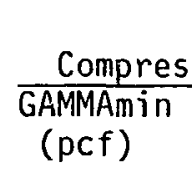 & $\frac{\text { lity }}{\text { BETA }}$ & $\begin{array}{l}\text { Permeability } \\
{[\text { KO (fps)] }} \\
\text { at room temp. }\end{array}$ & $\begin{array}{c}\text { Material } \\
\text { flow factor } \\
\text { (ff) at } 800 \mathrm{psf}^{\mathrm{a}}\end{array}$ & $\begin{array}{l}\text { PHI-PRIME on } \\
2 B \text { SS (deg) }\end{array}$ \\
\hline $\begin{array}{l}\text { Coal } \\
\text { KG } \frac{184}{205} \\
14 \underline{205}\end{array}$ & 114.2 & 31 & $\begin{array}{l}1.1 \mathrm{~A} / \mathrm{R} \\
2.4\end{array}$ & $\begin{array}{l}33.9 \\
36.0\end{array}$ & $\begin{array}{l}0.04615 \\
0.04883\end{array}$ & $\begin{array}{l}0.000787 \\
0.000915\end{array}$ & $\begin{array}{l}4.7 \\
3.8^{b}\end{array}$ & $\begin{array}{l}28 \text { to } 22 \\
30 \text { to } 27\end{array}$ \\
\hline $\begin{array}{l}\text { Coal } \\
\text { KG } \frac{183}{206} \\
14\end{array}$ & 90.4 & 45 & $\begin{array}{l}6.8 \mathrm{~A} / \mathrm{R} \\
7.5 \\
8.8\end{array}$ & $\begin{array}{l}33.7 \\
35.3 \\
33.2\end{array}$ & $\begin{array}{l}0.02668 \\
0.02880 \\
0.03196\end{array}$ & $\begin{array}{l}0.001128 \\
-- \\
0.001478\end{array}$ & $\begin{array}{l}-- \\
7.3 \\
7.6\end{array}$ & $\begin{array}{l}24 \text { to } 16 \\
25 \text { to } 21\end{array}$ \\
\hline $\begin{array}{l}\text { KMAC } \frac{162 C}{222} \\
\text { CPDU }\end{array}$ & 90.3 & 37 & $3.5 \mathrm{~A} / \mathrm{R}$ & 36.0 & 0.03490 & 0.011770 & 4.8 & 24 to 21 \\
\hline $\begin{array}{l}\text { KMAC } \frac{211}{224 A} \\
\text { CPDU }\end{array}$ & 85.1 & 22 & $3.1 \mathrm{~A} / \mathrm{R}$ & 21.5 & 0.04059 & 0.001580 & 10.0 & 29 to 28 \\
\hline $\begin{array}{l}\text { KMAC } 211 C \\
\text { CPDJ } 223\end{array}$ & 83.2 & 18 & $\begin{array}{l}2.4 \mathrm{~A} / \mathrm{R} \\
3.1 \\
7.1\end{array}$ & $\begin{array}{l}17.2 \\
15.1 \\
15.2\end{array}$ & $\begin{array}{l}0.04828 \\
0.06485 \\
0.06360\end{array}$ & $\begin{array}{l}0.000630 \\
0.001035 \\
0.000781\end{array}$ & $\begin{array}{l}4.6 \\
-- \\
3.9^{b}\end{array}$ & $\begin{array}{c}32 \\
-- \\
33^{c}\end{array}$ \\
\hline $\begin{array}{l}\text { KMAC } 212 \\
\text { CPDU } 225 A\end{array}$ & 90.1 & 17 & $\begin{array}{l}1.7 \mathrm{~A} / \mathrm{R} \\
2.7 \\
7.0\end{array}$ & $\begin{array}{l}16.4 \\
14.2 \\
14.9\end{array}$ & $\begin{array}{l}0.04740 \\
0.06448 \\
0.06776\end{array}$ & $\begin{array}{l}0.000335 \\
0.000667 \\
0.000572\end{array}$ & $\begin{array}{l}5.7 \\
-- \\
3.5^{b}\end{array}$ & $\begin{array}{c}25 \text { to } 18 \\
-35^{c}\end{array}$ \\
\hline
\end{tabular}

allerial cohesive strength increases as ff approaches one.

${ }^{b}$ Screw overloading is likely at low flow rates. See Conclusions.

Not suitable for mass flow. 
Table 2

Sanples of Simulation Results

\begin{tabular}{|c|c|c|c|c|c|c|c|c|c|}
\hline \multirow[b]{2}{*}{$\begin{array}{l}\text { Material } \\
\text { no. }\end{array}$} & \multicolumn{3}{|c|}{ Description } & \multirow{2}{*}{$\begin{array}{c}\text { Bin top } \\
\text { (SIGMA=0) } \\
\frac{\mathrm{dP} / \mathrm{dx}}{\text { GAMMA }}\end{array}$} & \multicolumn{2}{|c|}{ Bin bottom } & \multirow{2}{*}{$\begin{array}{c}\text { Convergence } \\
\text { iniet } \\
\mathrm{dP} \mathrm{P}^{\prime} \mathrm{dx} \\
\mathrm{GAMMA}\end{array}$} & \multicolumn{2}{|c|}{ Convergence outlet } \\
\hline & $\begin{array}{c}\text { Descript } \\
\text { Volatiles } \\
(\%)\end{array}$ & $\begin{array}{c}\text { on } \\
\text { Q } \\
(\mathrm{tph})\end{array}$ & Temp. & & $\begin{array}{l}\frac{B i n}{\text { SIGMA }} \\
\text { (psf) }\end{array}$ & $\frac{o m}{\frac{d P / d x}{G A M M A}}$ & & $\begin{array}{c}\text { (SIGMA }=0) \\
\frac{d P / d x}{G A M M A}\end{array}$ & $\frac{\mathrm{dSIGMA} / \mathrm{dx}}{\text { GAMMA }}$ \\
\hline \multirow[t]{3}{*}{184} & 1.1 & 5.6 & room & $\cong 0.6$ & 60 & -4.1 & -16 & 45 & -44 \\
\hline & & & & $\cong 0.6$ & 21 & -0.3 & -16 & 45 & -44 \\
\hline & & & & $\cong 0.6$ & 10 & 0.9 & -16 & 45 & -44 \\
\hline \multirow[t]{3}{*}{184} & 1.1 & 5.6 & $80^{\circ} \mathrm{C}$ & $\cong 0.7$ & 51 & -3.4 & -18 & 53 & -52 \\
\hline & & & & $\cong 0.7$ & 21 & -0.3 & -18 & 53 & -52 \\
\hline & & & & $\cong 0.7$ & 0 & 3.2 & -18 & 53 & -52 \\
\hline \multirow[t]{3}{*}{$162 \mathrm{C}$} & 3.5 & 7.6 & rcom & -0.1 & 42 & -2.0 & & & \\
\hline & & & & 0 & 20 & -0.5 & $-1) .2$ & 2.6 & $-2^{b}$ \\
\hline & & & & 0.15 & 4 & -0.8 & 4.9 & 9.5 & $-11^{\mathrm{b}}$ \\
\hline \multirow[t]{3}{*}{212} & 1.7 & 7.6 & room & $\cong 1.0$ & 15 & -1.0 & -32 & 282 & $-90^{b}$ \\
\hline & & & & $\cong 1.0$ & 9 & -1.0 & -11 & 243 & $-25^{\mathrm{b}}$ \\
\hline & & & & $\cong 1.0$ & 7 & 0 & -9 & 237 & $-19^{\mathrm{b}}$ \\
\hline \multirow[t]{2}{*}{212} & 1.7 & 5.6 & room & $\cong 1.0$ & 10 & -0.2 & -0.9 & 65 & $0^{\mathrm{b}}$ \\
\hline & & & & $\cong 1.0$ & 7 & 0 & $-\underline{G}$ & 175 & $-24^{b}$ \\
\hline \multirow[t]{2}{*}{212} & 1.7 & 3 & room & $\cong 1.0$ & 20 & -2.5 & $-2 T$ & 110 & $-65^{b}$ \\
\hline & & & & $\cong 1.0$ & 12 & 0 & -28 & 111 & $-68^{b}$ \\
\hline \multirow[t]{3}{*}{212} & 1.7 & 1.5 & room & $\cong 0.8$ & 39 & -5.0 & -20 & 60 & -61 \\
\hline & & & & $\cong 0.8$ & 18 & -1.4 & -20 & 60 & -61 \\
\hline & & & & $\cong 0.8$ & 4 & 1.4 & -20 & 60 & -61 \\
\hline
\end{tabular}

${ }_{b}^{\text {Calculated }} 0.25$ in. from convergence outlet.

Unstable ("spitting") behavior is likely. 
Table 3

Scale Parameter for Feed System

\begin{tabular}{cccc}
\hline Material & $\begin{array}{c}\text { Volatile content } \\
(\text { wt \%) }\end{array}$ & $\begin{array}{c}\text { Bin flow } \\
\text { rate, } \\
(\text { tph })\end{array}$ & $\begin{array}{c}\text { Scale façtor, } \\
\text { Vs/k0 } \\
\text { (dimensionless) }\end{array}$ \\
\hline 184 & 1.1 & 5.6 & $460^{\mathrm{b}}$ \\
183 & 2.4 & 5.6 & 372 \\
& 6.8 & 7.93 & $457^{\mathrm{b}}$ \\
$162 \mathrm{C}$ & 8.8 & 7.93 & 354 \\
211 & 3.5 & 7.6 & 39 \\
$211 \mathrm{C}$ & 3.1 & 7.6 & $490^{\mathrm{C}}$ \\
& 2.4 & 7.6 & $1,536^{\mathrm{C}}$ \\
212 & 3.1 & 7.6 & $1,065^{\mathrm{C}}$ \\
& 1.7 & 7.6 & $3,030^{\mathrm{C}}$ \\
& 2.7 & 7.6 & $1,757^{\mathrm{C}}$ \\
& 1.7 & 1.5 & $598^{\mathrm{C}}$ \\
& 2.7 & 1.5 & $347^{2}$ \\
\hline
\end{tabular}

${ }^{a}$ Average solid velocity exiting convergence divided by permeability parameter $\mathrm{KO}$ corrected to $80^{\circ} \mathrm{C}$.

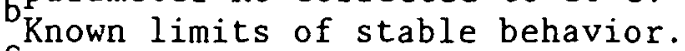

"Unstable ("spitting") behavior likely. 
Table 4

Physical Properties of Test Material:

\begin{tabular}{|c|c|c|c|c|c|c|}
\hline Sample date & :1) & (1) & $4 / 30 / 79$ & $6 / 27,80$ & $6 / 22 / 80$ & $7 / 28 / 80$ \\
\hline Bulk density, $1 \mathrm{~b} / \mathrm{ft}^{3}$ & 41 & 40 & 38 & 25 & 20 & 21 \\
\hline C & i1) & (1) & (1) & 70.75 & 70.73 & 70.73 \\
\hline$H$ & & & & 4.81 & 4.81 & 4.81 \\
\hline$N$ & & & & $1.3 \varepsilon$ & 1.38 & 1.38 \\
\hline 0 & & & & 11.60 & 11.60 & 11.60 \\
\hline
\end{tabular}

(1) Not available. 
Figure 1

Elastic Analysis of Convergence

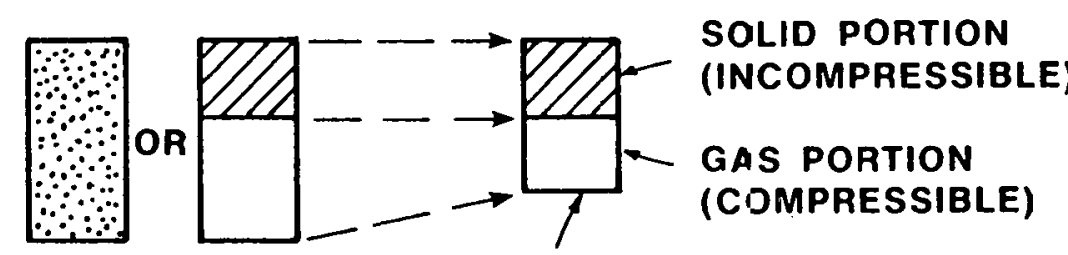

ASSUMPTIONS (CONSERVATIVE):

PERFECT GAS, EXTREMELY LOW PERMEABILITY PREVENTS SIGNIFICANT GAS FLOW, AND BULK DENSITY ENTERING CONVERGENCE IS MINIMUM.

CR $\rightarrow$ COMPRESSION RATIO (2.3)

$P_{f} / P_{i} \simeq 3.2$

$14,500,000$ psf

5.1 
Figure 2

Example of Solid and Gas Pressure Distributions

1 for Coal 184

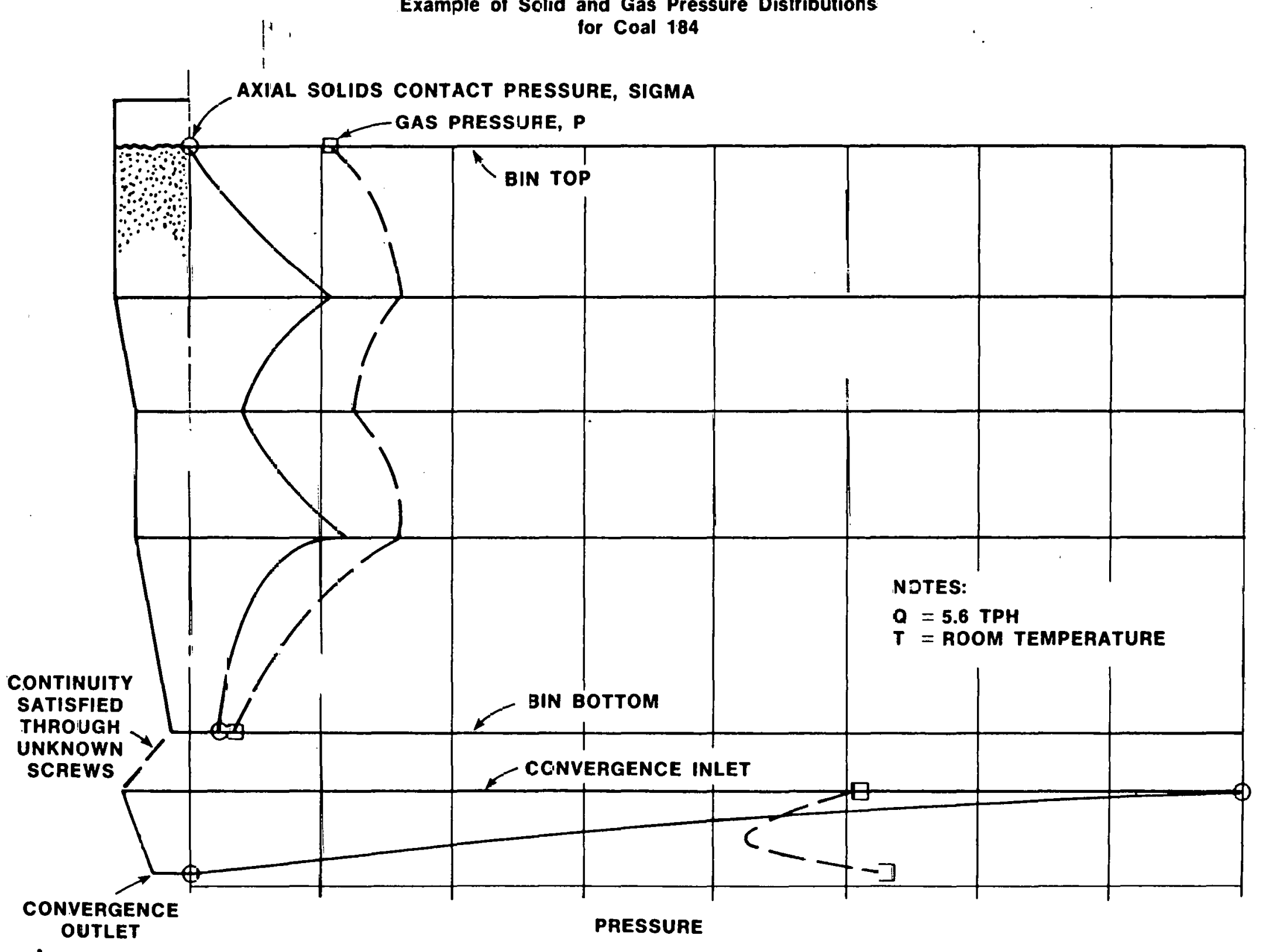


Figure 3

Example of Solid and Gas Pressure Distributions

for KMAC 212

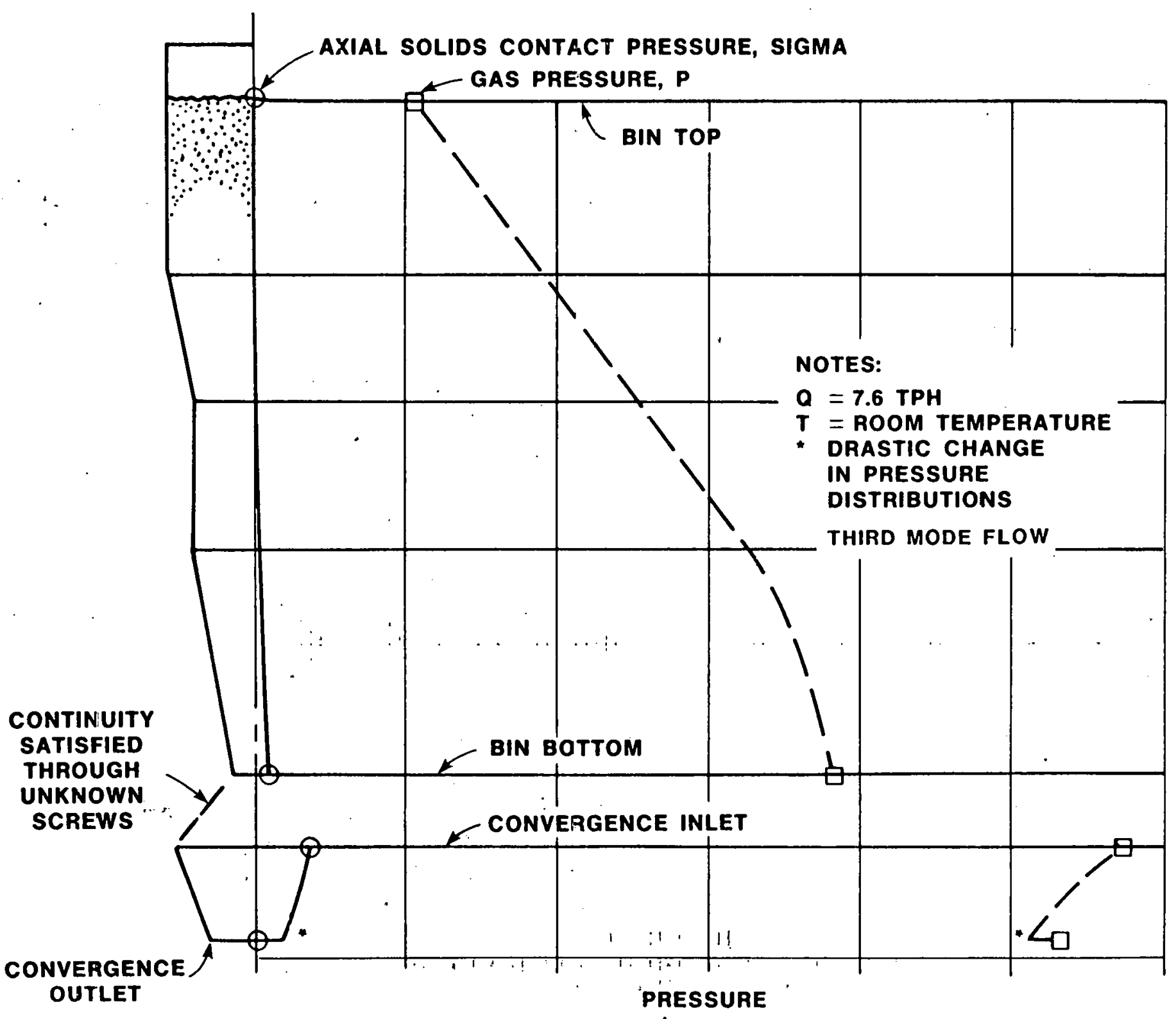


Figure 4

Example of Solid and Gas Pressure Distributions

for KMAC 212 at Low Solids Flow Rate

AXIAL SOLIDS CONTACT PRESSURE, SIGMA

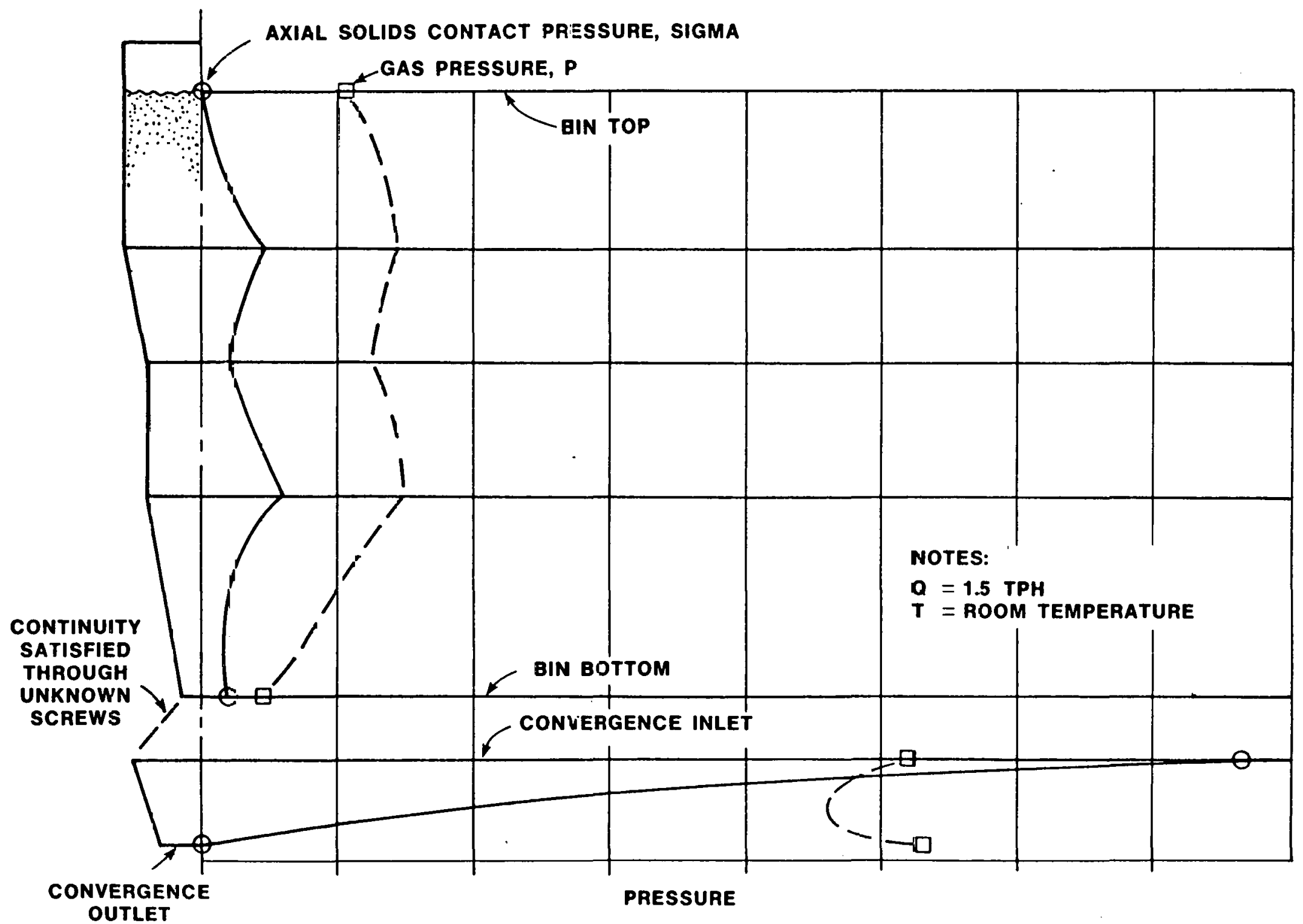


Appendix A

Standard Test Report:

Coal Flow Properties 


\section{INTRODUCTION}

This test report describes the flow properties of the pulverized coal samples provided by GKT. These properties are expressed in terms of bin dimensions required to ensure dependable flow, maximum hopper angles for mass flow, and critical discharge rates through bin outlets. All dimensions represent limiting conditions for flow; therefore, larger outlets, steeper hoppers, and flow rates below critical are acceptable. Appendix $C$ is provided to familiarize the reader with the use of this type of data. A glossary of terms and symbols is provided on pages C11 to C13. Most of the symbols used in the report are shown in the figures on pages C14 to C16. The concepts of gravity flow of solids, and examples of application of solids flow data are further illustrated by Johanson (1978a\&b, 1979).

\section{GENERAL COMMENTS}

Pulverized coals 183 and 184 were chosen for testing from the five coal samples provided by GKT since they are the finest bituminous and lignite, respectively, which indicates more difficulty in handling. These coals were tested primarily at $176^{\circ} \mathrm{F}\left(80^{\circ} \mathrm{C}\right)$ to determine their flow properties at the extremes of volatile (moisture) content, at which GKT indicated that handling problems occur. These results are summarized in Table 1 (pağe 15).

In general, increasing volatile content. slightly increased material compressibility (BETA), permeability (KO), cohesive strength (decreasing ff), and wall friction angles (PHI-PRIME).

Volatile content was determined by holding $10 \mathrm{~g}$ samples of coal at $107^{\circ} \mathrm{C}$ in a dry nitrogen atmosphere until no change in weight occurred (2-4 hr). Increasing volatile content was accomplished by blending the sample with atomized water in a commercial Hobart mixer. (This mixer, which is very similar to the household appliance, is composed of a bowl with a centered paddle arm.) Volatiles lost over the course of testing at $80^{\circ} \mathrm{C}$ were about $0.5 \mathrm{wt} \%$, except for the time consolidation and adhesion tests, in which about 1.2 wt \% was lost. Room temperature 
tests showed no appreciable differences in material flow properties from those at $80^{\circ} \mathrm{C}$, and the samples experienced negligible volatile loss. Data from tests performed on bulk material sample no. 1 are presented here as an example of the detailed information compiled for each coal sample. 


\section{SUMMARY OF TESTS PERFORMED}

Th1s report presents various flow property test results as indicated for the following material(s):

BULK

MATERIAL DESCRIPTION

$\begin{array}{ll}1 & \text { COAL } 184 \\ 2 & \text { COAL } 184 \\ 3 & \text { COAL } 183 \\ 4 & \text { COAL } 183 \\ 5 & \text { COAL } 183\end{array}$

$1 \quad$ COAL 184

COAL 184

COAL 183

COAL 183

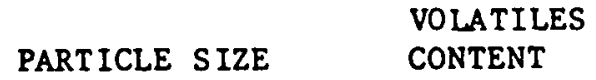

AS REC'D
AS REC'D
AS REC'D
AS REC'D
AS REC'D

$A / R(1.1 \%)$

$2.4 \%$

A/R $(6.8 \%)$

$7.5 \%$

$8.8 \%$

\begin{tabular}{|c|c|c|c|c|c|c|c|}
\hline $\begin{array}{c}\text { BULK } \\
\text { MATERIAL }\end{array}$ & $\begin{array}{c}\text { TIME } \\
\text { hr }\end{array}$ & $\begin{array}{l}\text { TEMPERATURE } \\
{ }^{\circ} \mathrm{F}\end{array}$ & $\begin{array}{l}\text { RELAT IVE } \\
\text { HUMIDITY }\end{array}$ & $\begin{array}{l}\text { BIN } \\
\text { DIM }\end{array}$ & $\begin{array}{c}\text { BULK } \\
\text { DENSITY }\end{array}$ & $\begin{array}{l}\text { HOP PER } \\
\text { ANGLES }\end{array}$ & $\begin{array}{l}\text { CHUTE } \\
\text { ANGLES }\end{array}$ \\
\hline 1 & 0.0 & 176 & NA & $x$ & $x$ & $x$ & \\
\hline 2 & $\begin{array}{r}0.0 \\
18.0\end{array}$ & $\begin{array}{l}1 / 6 \\
176\end{array}$ & $\begin{array}{l}\text { NA } \\
\text { NA }\end{array}$ & $\begin{array}{l}x \\
x\end{array}$ & $x$ & $\begin{array}{l}x \\
x\end{array}$ & \\
\hline 3 & 0.0 & 176 & NA & & $x$ & $x$ & \\
\hline 4 & 0.0 & 72 & NA & $x$ & $x$ & & \\
\hline 5 & $\begin{array}{r}0.0 \\
18.0 \\
20.0\end{array}$ & $\begin{array}{l}176 \\
176 \\
176\end{array}$ & $\begin{array}{l}\text { NA } \\
\text { NA } \\
\text { NA }\end{array}$ & $\begin{array}{l}x \\
X\end{array}$ & $x$ & $x$ & \\
\hline
\end{tabular}


BULK MATERIAL 1: COAL 184

PARTICLE SIZE AS REC'D

MOISTURE CONTENT A/R(1.1\%)

SECTION I. BT.N DTMFNSTONS FOR DEPENDABLE FLOW (In fE)

STORAGE TIME AT REST $0.0 \mathrm{hr}$

TEMPERATURE 176 DEG F

PART A. BINS WITH UNLIMITED MAXIMUM SIZE

\begin{tabular}{|c|c|c|c|c|c|c|c|c|c|c|}
\hline \multirow{3}{*}{ P-FACTOR } & MASS & FLOW & \multicolumn{3}{|c|}{ F U N N E L } & \multicolumn{2}{|c|}{ F $L O \mathrm{~W}$} & \multirow{3}{*}{20} & \multirow{3}{*}{25} & \multirow{3}{*}{$f t$} \\
\hline & $\mathrm{BC}$ & BP & BF & $\mathrm{EH}=$ & 2.5 & 5 & 10 & & & \\
\hline & $t t$ & ft & ft & & & & & & & \\
\hline 1.00 & 0.4 & 0.2 & 0.2 & $\mathrm{DF}=$ & 2.1 & 4.1 & 8 & 13 & 15 & ft \\
\hline 1.25 & 0.5 & 0.2 & 0.3 & $\mathrm{DF}=$ & 2.5 & 5 & 9 & 15 & 17 & ft \\
\hline 1.50 & 0.7 & 0.4 & 0.5 & $\mathrm{DF}=$ & 2.9 & 6 & 11 & 16 & 18 & ec \\
\hline 2.00 & 2.7 & 1.2 & 2.3 & $\mathrm{DF}=$ & 3.9 & 8 & 13 & 19 & 21 & ft \\
\hline
\end{tabular}


BULK MATER IAL 1: COAL 184

PARTICLE SIZE AS REC'D

MOISTURE CONTENT A/R(1.1\%)

SECTION II. BULK DENSITY

TEMPERATURE 176 deg F

$\begin{array}{lllllllll}\text { EH, ft } & 0.5 & 1.0 & 2.5 & 5.0 & 10.0 & 20.0 & 40.0 & 80.0\end{array}$

SIGMA1, psf 21. 43. 113. 235. 485. 1003. 2075. 4291.

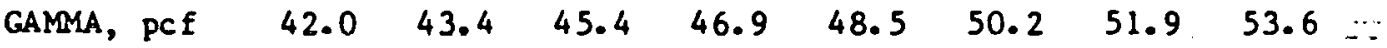

COMPRESSIBILITY PARAMETERS

Bulk density GAMM, is a function of the principal consolidating pressure SIGMA., as follows:

$$
\text { GAMMA - GAMMAO (SIGMAI / SIGMAO) }
$$

For GAMMA between 43.4 and 52.2 pcf

GAMMAO $=41.0$ pCf

SIQMAO $=13.0 \mathrm{PSF}$

$B E T A=0.04615$

GAMMA MINIMUM $=33.9 \mathrm{pCf}$ 
BULK MATER IAL 1: COAL 184

PARTICLE SIZE AS REC'D

MOISTURE CONTENT A/R(1.1\%)

SECTION III. MAXIMUM HOPPER ANGLES FOR MASS-FLOW

WALL MATERIAL: 304-\#2B STAINLESS STEEL SHEET

STORAGE TIME AT REST 0.0 hrs

TEMPERATURE $176 \mathrm{deg}$

HOPPER ANGLES FOR VARIOUS HOPPER SPANS

\begin{tabular}{|c|c|c|c|c|c|c|}
\hline $\begin{array}{l}\text { WIDTH OF OVAL, ft } \\
\text { DIA OF CONE, ft }\end{array}$ & $\begin{array}{l}0.11 \\
0.22\end{array}$ & $\begin{array}{l}0.25 \\
0.50\end{array}$ & $\begin{array}{l}0.5 \\
1.0\end{array}$ & $\begin{array}{l}1.0 \\
2.0\end{array}$ & $\begin{array}{l}2.0 \\
4.0\end{array}$ & $\begin{array}{l}4.0 \\
8.0\end{array}$ \\
\hline $\begin{array}{l}\text { WalI Friction Angle } \\
\text { PHI-PRIME, deg }\end{array}$ & 28. & 28. & 28. & 28. & 27. & 26. \\
\hline $\begin{array}{l}\text { Hopper Angles } \\
\text { THETA-P, deg } \\
\text { THETA-C, deg }\end{array}$ & $\begin{array}{l}24 . \\
12\end{array}$ & $\begin{array}{l}24 \\
12\end{array}$ & $\begin{array}{l}24 . \\
12 .\end{array}$ & $\begin{array}{l}24 . \\
12 .\end{array}$ & $\begin{array}{l}25 . \\
13 .\end{array}$ & $\begin{array}{l}26 . \\
14 .\end{array}$ \\
\hline
\end{tabular}

WALL MATERIAL: AGED CARBON STEEL

STORAGE TIME AT REST 0.0 hrs

TEMPERATURE $176 \mathrm{deg}$ F

HOPPER ANGLES FOR VARIOUS HOPPER SPANS

$\begin{array}{llllllll}\text { WIDTH OF OVAL, ft } & 0.11 & 0.25 & 0.5 & 1.0 & 2.0 & 4.0 & 10.1 \\ \text { VIA OF CONE, ft } & 0.22 & 0.50 & 1.0 & 2.0 & 4.0 & 8.0 & 20.2\end{array}$

Wall Friction Angle

PHI-PRIME, deg 36. 36. 36. 36. 36. $34 . \quad 30$.

Hopper Angles

THETA-P, deg 17. 17. 17. 17. 17. $18 . \quad 20$.

THETA-C, deg

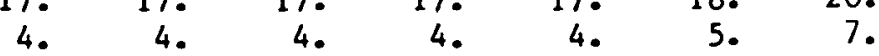

Note: Flow along walls is questionable for oval widths less than $7.0 \mathrm{ft}$ and contcal diameters less than $14.0 \mathrm{ft}$. 
BULK MATER IAL 1: COAL 184

PARTICLE SIZE AS REC'D

MOISTURE CONTENT A/R(1.1\%)

SECTION IV. CRITICAL SOLIDS FLOW RATE

TEMPERATURE $176 \mathrm{deg}$ F

CONICAL MASS-FLOW HOPPER

Flow rate expressed in units of tons/hr.

BC $\quad \mathrm{EH}=2.5 \mathrm{ft} \quad 5.0 \mathrm{ft} \quad 10.0 \mathrm{ft} \quad 20.0 \mathrm{ft} \quad 40.0 \mathrm{ft}$

$\begin{array}{lccccc}0.50 \mathrm{ft} & 0.09 & 0.08 & 0.07 & 0.07 & 0.06 \\ 1.00 \mathrm{ft} & 0.35 & 0.32 & 0.30 & 0.28 & 0.26 \\ 2.00 \mathrm{ft} & 1.4 & 1.2 & 1.1 & 1.1 & 1.0 \\ 4.00 \mathrm{ft} & 5.6 & 5.1 & 4.7 & 4.4 & 4.1 \\ 8.00 \mathrm{ft} & 23 . & 21 . & 19 . & 18 . & 17 .\end{array}$

TPANSITION MASS-FI.NW HOPPER

Flow rate expressed in units of tons/hr per foot length of outlet.
BP
$\mathrm{EH}=$
$2.5 \mathrm{ft}$
$5.0 \mathrm{ft}$
$10.0 \mathrm{ft}$
$20.0 \mathrm{ft}$
$40.0 \mathrm{ft}$

$0.25 \mathrm{ft}$

$0.50 \mathrm{ft}$

0.11

0.23

0.45

$2.00 \mathrm{ft}$

$4.00 \mathrm{tt}$

$8.00 \mathrm{ft}$

0.90

1.8

3.6

0.10

0.09

0.19

0.38

0.41

0.82

1. 6

0.76

1. 5

3.2

3.0

0.09

0.08

0.18

0.16

0.35

0.33

0.70

1.4

0.66

2.8

1. 3

2.6 
BULK MATER IAL 1: COAL 184

PARTICLE SIZE AS REC'D

MOISTURE CONTENT A/R(1.1\%)

\section{SECTION V. AIR PERMEABILITY TEST RESULTS}

TEMPERATURE $176 \mathrm{deg}$ F

$K$, the air permeability factor of the solid is defined from narcy's low in the Eollowing form:

$$
k=-u(\text { GAMMA) / }(d p / d x)
$$

where:

$u$ - superficial gas velocity through the bed of solids

$d p / d x=$ gas pressure gradient across the bed

GAMA = bulk density of the solid in the bed

$K$ is a function of the bulk density of the solid

$$
K=\mathrm{KO} \text { (GAMMA / GAMMAO) }
$$

At roum temperacure, for GAMMA between 40.7 and 52.9 pcf:

$$
\mathrm{KO}=0.000787 \mathrm{fps}
$$

GAMMO $=41.0 \mathrm{pCF}$

$a=5.15$ 

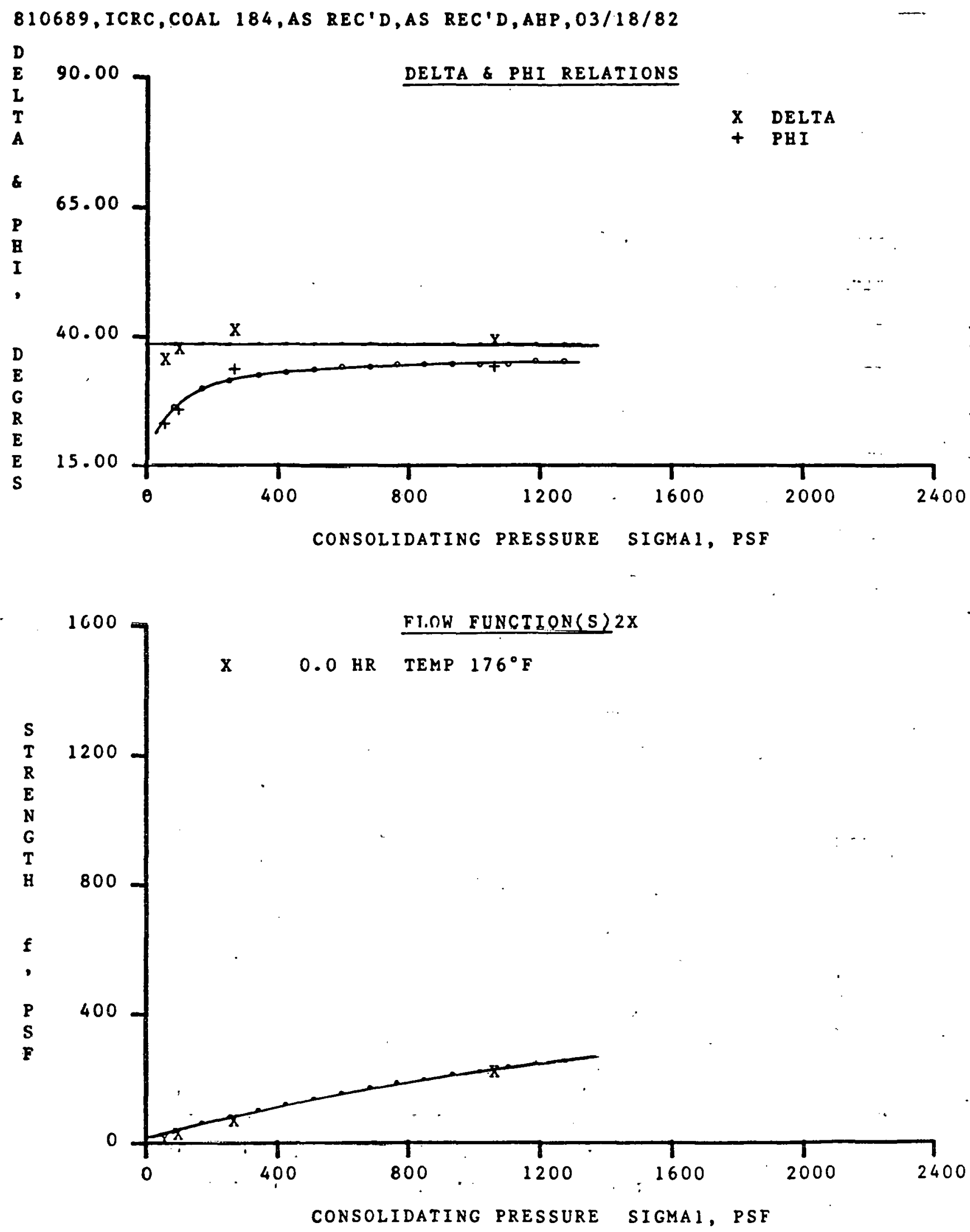
10689,ICRC,COAL 184,AS REC'D,AS REC'D,AHP,03/18/82

\section{YIELD LOCUS}

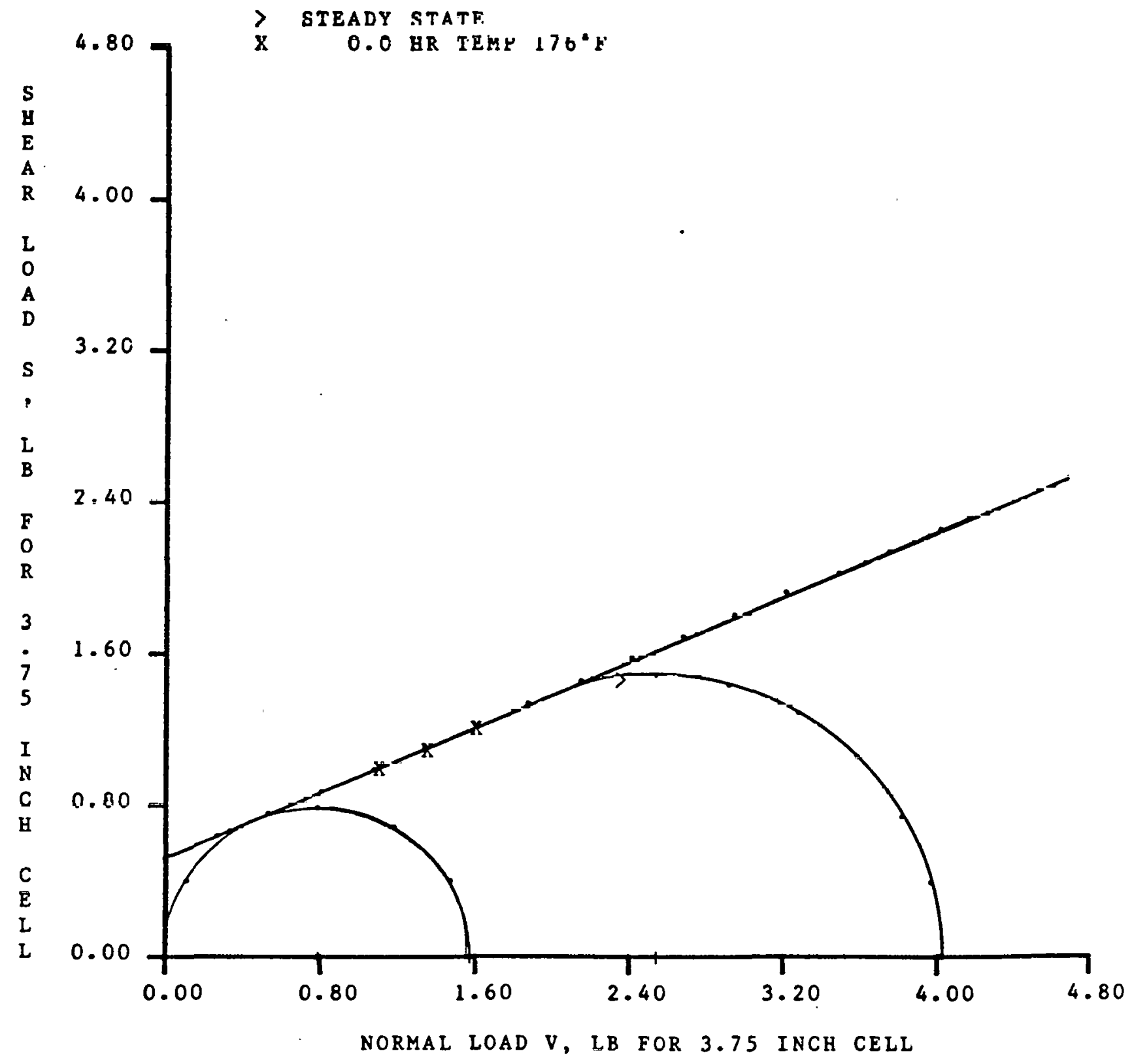


Appendix B

Standard Test Report:

KMAC Flow Properties 


\section{INTRODUCTION}

This test report describes the flow properties of the KMAC samples provided by ICRC. These properties are expressed in terms of bin dimensions required to ensure dependable flow, maximum hopper angles for mass flow, and critical discharge rates through bin outlets. All dimensions represent limiting conditions for flow; therefore, larger outlets, steeper hoppers, and flow rates below critical are acceptable.

Appendix $C$ is provided to familiarize the reader with the use of this type of data. A glossary of terms and symbols is provided on pages C11 to C13. Most of the symbols used in the report are shown in the figures on pages C14 to C16. The concepts of gravity flow of solids, and examples of application of solids flow data are further illustrated by Johanson (1978a\&b, 1979).

\section{GENERAL COMMENTS}

KMACs $162 \mathrm{C}$ (a coarse ash generated during an upset), 211, 211C, and 212 were tested primarily at room temperature $\left(72^{\circ} \mathrm{F}\right)$ to determine their flow properties. Preliminary tests indicated that the material flow properties are not significantly affected by temperatures between 72 and $176^{\circ} \mathrm{F}$.

All samples were tested at their "as received" volatiles content, and the finer samples, $211 \mathrm{C}$ and 212, were also tested at increased volatile (moisture) content to compare with the flow properties of the GKT coals. The results of these tests are summarized in Table 1 (page 15).

In general, increasing the volatile content by about 1 wt \% slightly increased material compressibility (BETA), permeability (KO), cohesive strength (decreasing $f f$ ), and wall friction angles (PHI-PRIME). Increasing the volatiles by an additional 4 wt \% caused no significant further change in flow properties. At the high volatile content tested ( 7 wt \%), mass flow will not occur on mill finish carbon steel plate and 2B stainless steel sheet finishes. 
Volatile content was determined by holding $10 \mathrm{-g}$ samples of KMAC at $107^{\circ} \mathrm{C}$ in a dry nitrogen atmosphere until no change in weight occurred $(2-4 \mathrm{hr})$. Increasing the volatile content was accomplished by blending the sample with atomized water in a commercial Hobart mixer. About 0.5 wt $\%$ volatiles were lost over the course of room temperature tests. Data from tests performed on bulk material sample no. 1 are presented here as an example of the detailed information compiled for each KMAC sample. 


\section{SUMMARY OF TESTS PERFORMED}

This report presents various flow property test results as indicated for the following materlal(s):

$\begin{array}{cl}\begin{array}{c}\text { BULK } \\ \text { MATERIAL }\end{array} & \text { DESCRIPT } \\ & \\ 1 & \text { KMAC } 162 C \\ 2 & \text { KMAC 211 } \\ 3 & \text { KMAC 211C } \\ 4 & \text { KMAC 211C } \\ 5 & \text { KMAC 211C } \\ 6 & \text { KMAC 212 } \\ 7 & \text { KMAC 212 } \\ 8 & \text { KMAC 212 }\end{array}$

PARTICLE SIZE

$-6 M$

AS REC'D

AS REC'D

AS REC'D

AS REC'D

AS KEC'D

AS REC'D

AS REC'D

$\begin{array}{ll}\text { VOLATILES } & \text { PYRADINE } \\ \text { CONTENT } & \text { SOLUBLES }\end{array}$

$A / R(3.5 \%) \quad 36 \%$

A/R (3.1\%) $\quad 37 \%$

$A / R(2.4 \%) \quad 47 \%$

$3.1 \%$

$7.1 \%$

$A / R(1.7 \%)$

$2.7 \%$

$7.0 \%$
$---$

$40 \%$

--

\begin{tabular}{|c|c|c|c|c|c|c|c|c|c|}
\hline $\begin{array}{c}\text { BULK } \\
\text { MATERIAL }\end{array}$ & $\begin{array}{l}\text { TIME } \\
\text { hr }\end{array}$ & $\begin{array}{l}\text { TEMPE RATURE } \\
{ }^{\circ} \mathrm{F}\end{array}$ & $\begin{array}{l}\text { RELATIVE } \\
\text { HUMIDITY }\end{array}$ & $\begin{array}{l}\text { BIN } \\
\text { DIM }\end{array}$ & $\begin{array}{c}\text { BULK } \\
\text { DENSITY }\end{array}$ & $\begin{array}{l}\text { HOPPER } \\
\text { ANGLES }\end{array}$ & $\begin{array}{l}\text { CHUTE } \\
\text { ANGLES }\end{array}$ & $\begin{array}{l}\text { FLOW } \\
\text { RATE }\end{array}$ & OTHER \\
\hline 1 & 0.0 & 72 & NA & $x$ & $x$ & $x$ & & $x$ & \\
\hline 2 & 0.0 & 72 & NA & $x$ & $\mathbf{x}$ & $x$ & & $x$ & \\
\hline 3 & 0.0 & 72 & NA & $x$ & $x$ & $x$ & & $x$ & \\
\hline 4 & 0.0 & 72 & NA & & $x$ & & & $x$ & \\
\hline 5 & 0.0 & 72 & NA & $x$ & $\mathrm{X}$ & $x$ & & $x$ & \\
\hline 6 & $\begin{array}{r}0.0 \\
22.0\end{array}$ & $\begin{array}{l}176 \\
176\end{array}$ & $\begin{array}{l}\text { NA } \\
\text { NA }\end{array}$ & $\begin{array}{l}\mathrm{X} \\
\mathrm{X}\end{array}$ & $x$ & $\begin{array}{l}x \\
x\end{array}$ & & $x$ & \\
\hline 7 & 0.0 & 72 & NA & & $\mathrm{X}$ & & & $x$ & \\
\hline 8 & 0.0 & 72 & NA & 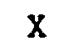 & $X$ & $x$ & & $x$ & \\
\hline
\end{tabular}




\section{BULK MATERLAL 1: KMAC 162C \\ PARTICLE SIZE -6M \\ MOISTURE CONTENT A/R(3.5\%)}

SECTION I. BIN DIMENSIONS FOR DEPENDABLE FLOW (in $\mathrm{ft}$ )

STORAGE TIME AT REST $0.0 \mathrm{hr}$

TEMPERATURE 72 DEG F

PART A. BINS WITH UNLIMITED MAXIMUM SIZE

$$
\begin{aligned}
& \text { MASS FLOW FUNNEL F L O W }
\end{aligned}
$$

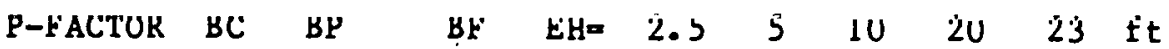

$$
\begin{aligned}
& \text { ft ft ft } \\
& 1.00 \quad 0 . * 0 . * \quad 0 . * \quad D F=2.04 .0 \quad 8 \quad 16 \quad 19 \text { ft } \\
& 1.25 \text { U.* U.* U.* DFE } 2 . b 5 . \dot{0} 10 \quad 20 \quad 23 \text { ft } \\
& 1.50 \quad 0 . * 0 . * \quad 0 . * \quad \mathrm{DF}=3.0 \cdot 6 \quad 12 \quad 24 \quad 28 \mathrm{ft} \\
& 2.00 \quad 0 . * 0 . * \quad 0 . * \quad D F=3.9 \quad 8 \quad 16 \quad 32 \quad 36 \text { ft }
\end{aligned}
$$

interlocking, flow rate, etc. 
BULK MATERIAL 1: KMAC 162C

PARTICLE SIZE -6M

MOISTURE CONTENT A/R(3.5\%)

SECTION II. BULK DENSITY

TEMPERATURE $72 \mathrm{deg} F$

$\begin{array}{lllllllll}\text { EH, ft } & 0.5 & 1.0 & 2.5 & 5.0 & 10.0 & 20.0 & 40.0 & 80.0\end{array}$

SIGMA1, pSE 19. 39. 101. 208. 426. 873. 1791. 3673.

GAMMA, pCf $\quad 38.2 \quad 39.2 \quad 40.5 \quad 41.5 \quad 42.6 \quad 43.7 \quad 44.8 \quad 45.9$

COMPRESS IBILITY PARAMETERS

Bulk density GAMA, is a function of the principal consolidating pressure SIGMAl, as follows:

GAMMA = GAMMAO (SIGMAI / SIGMAO)

For GAMMA between 39.5 and $45.4 \mathrm{pcf}$

$$
\begin{aligned}
& \text { GAMMAO }=37.7 \mathrm{pCF} \\
& \text { SIGMAO }=13.0 \mathrm{psF} \\
& \text { BETA }=0.03490
\end{aligned}
$$

GAMMA MINIMUM $=36.0$ pCf 


\section{BULK MATERIAL 1: MMAC 162C \\ PARTICLE SIZE -6M \\ MOISTURE CONTENT A/R(3.5\%)}

SECTION III. MAXIMUM HOPPER ANGLES FOR MASS-FLOW

WALL MATERIAL: 304 2B STAINLESS STEEL SHEET

STORACE TIYE AT REET 0.0 hrs

TEMPERATURE $72 \mathrm{deg} F$

HOPPER ANGLES FOR VARIOUS HOPPER SPANS

$\begin{array}{llllllll}\text { WIDTH OF OVAL, ft } & 0.12 & 0.25 & 0.5 & 1.0 & 2.0 & 4.0 & 11.4 \\ \text { DIA OF CONE, ft } & 0.24 & 0.50 & 1.0 & 2.0 & 4.0 & 8.0 & 22.9 \\ \begin{array}{l}\text { Wall FrIction Angle } \\ \text { PHI-PR DME, deg }\end{array} & 24 . & 24 . & 24 . & 24 . & 24 . & 23 . & 21 . \\ & & & & & & & \\ \begin{array}{l}\text { Hopper Angles } \\ \text { THETA-P, deg }\end{array} & 28 . & 28 . & 28 . & 28 . & 28 . & 30 . & 33 . \\ \text { THETA-C, deg } & 18 . & 18 . & 18 . & 18 . & 18 . & 19 . & 22 .\end{array}$




\section{BULK MATER IAL 1: WMAC 162C \\ PARTICLE SIZE -6M \\ MOISTURE CONTENT A/R(3.5\%)}

SECTION IV. CRITICAL SOLIDS FLOW RATE

TEMPERATURE $176 \mathrm{deg} F$

CONICAL MASS-FLOW HOPPER

Flow rate expressed in units of tons/hr.

$\mathrm{BC} \quad \mathrm{EH}=2.5 \mathrm{ft} \quad 5.0 \mathrm{ft} \quad 10.0 \mathrm{ft} \quad 20.0 \mathrm{ft} \quad 40.0 \mathrm{ft}$

$\begin{array}{lccccc}0.25 \mathrm{ft} & 0.37 & 0.31 & 0.27 & 0.23 & 0.21 \\ 0.50 \mathrm{ft} & 1.4 & 1.2 & 1.0 & 0.94 & 0.84 \\ 1.00 \mathrm{ft} & 5.9 & 4.9 & 4.2 & 3.7 & 3.3 \\ 2.00 \mathrm{ft} & 24 . & 20 . & 17 . & 15 . & 13 . \\ 4.00 \mathrm{ft} & 95 . & 79 . & 68 . & 60 . & 54 . \\ 8.00 \mathrm{ft} & 380 . & 320 . & 270 . & 240 . & 210 .\end{array}$

TRANSITION MASS-FLOW HOPPER

Flow rate expressed in units of tons/hr per foot length of outlet. BP EH $=2.5 \mathrm{ft} \quad 3.0 \mathrm{ft} \quad 10.0 \mathrm{ft} \quad 20.0 \mathrm{ft} \quad 40.0 \mathrm{ft}$

$\begin{array}{llllll}0.25 \mathrm{ft} & 1.8 & 1.5 & 1.3 & 1.1 & 1.0 \\ 0.50 \mathrm{ft} & 3.7 & 3.1 & 2.7 & 2.3 & 2.1 \\ 1.00 \mathrm{ft} & 7.5 & 6.2 & 5.4 & 4.7 & 4.2 \\ 2.00 \mathrm{ft} & 15 . & 13 . & 11 . & 9.5 & 8.5 \\ 4.00 \mathrm{ft} & 30 . & 25 . & 22 . & 19 . & 17 . \\ 8.00 \mathrm{ft} & 60 . & 50 . & 43 . & 38 . & 34 .\end{array}$


BULX MATER IAL 1: KMAC 162C

PARTICLE SIZE -6M

MOISTURE CONTENT A/R(3.5\%)

SECTION V. AIR PERMEABILITY TEST RESURTS

TEMPE RATURE 72 deg F

$K$, the alr permeability factor of the solld is defined from Darcy ${ }^{\circ} s$ law in the follnwing form:

$$
K=-u(\text { GAPMA }) /(d \mathrm{p} / \mathrm{dx})
$$

where:

$u=$ superficial gas velocity through the bed of sollds

$d p / d x=$ gas pressure gradient across the bed

GAMMA = bulk density of the solld in the bed

$K$ is a function of the bulk density of the solid

$$
k=\text { Ko (CAMMA / GAMMO) }
$$

At room temperature, for GAMM between 39.0 and 47.4 pcf:

$$
\text { KO }=0.011770 \text { fps }
$$

GAMMO $=37.7$ pEf

$a=4.61$ 
810689, ICRC, KMAC $162 C, A / R(3.5 \%),-6 M, A B P, 07 / 22 / 82$
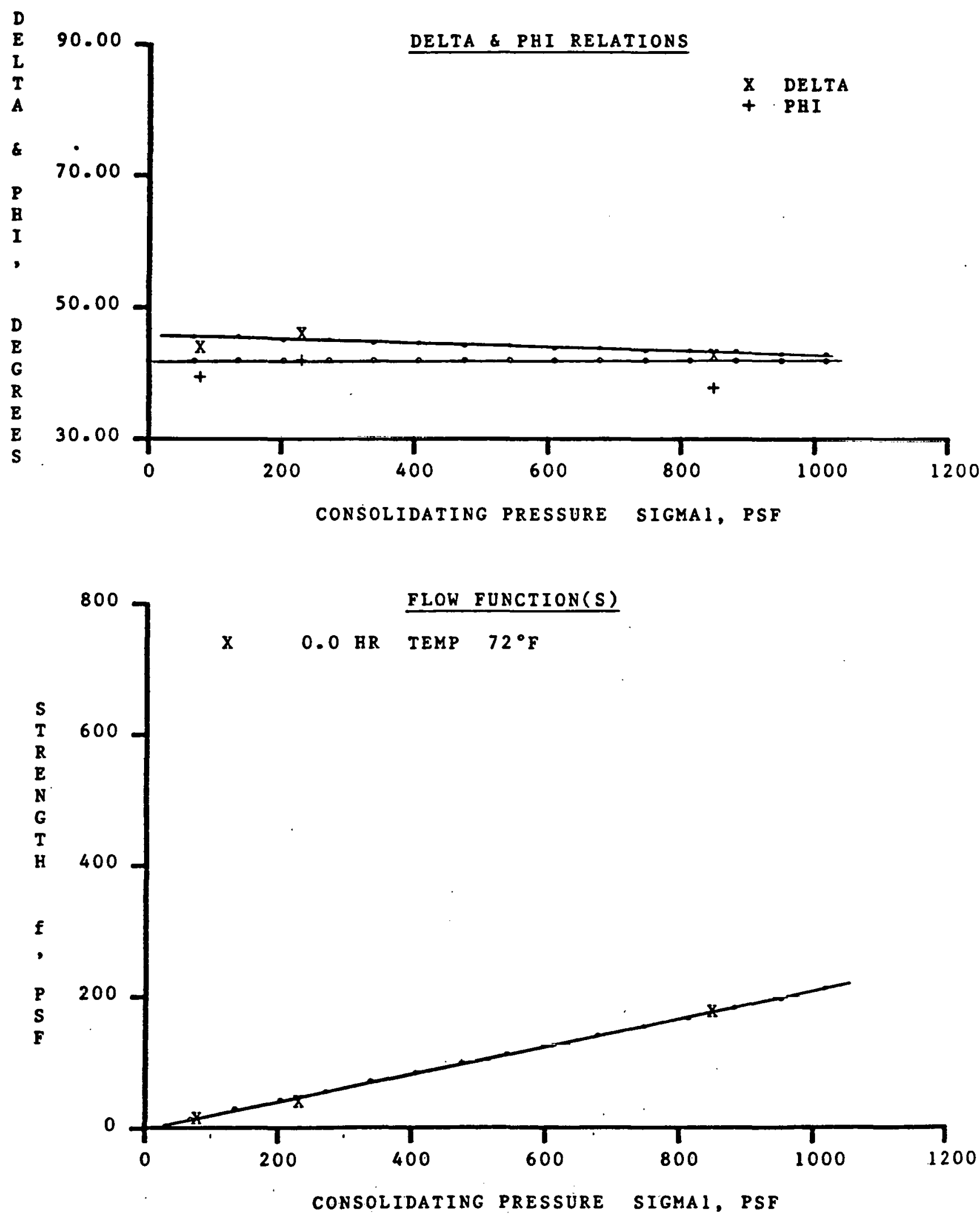
810689, ICRC, RMAC $162 \mathrm{C}, \mathrm{A} / \mathrm{R}(3.5 \%),-6 \mathrm{M}, \mathrm{AHP}, 07 / 22 / 82$

\section{YIELD LOCUS}

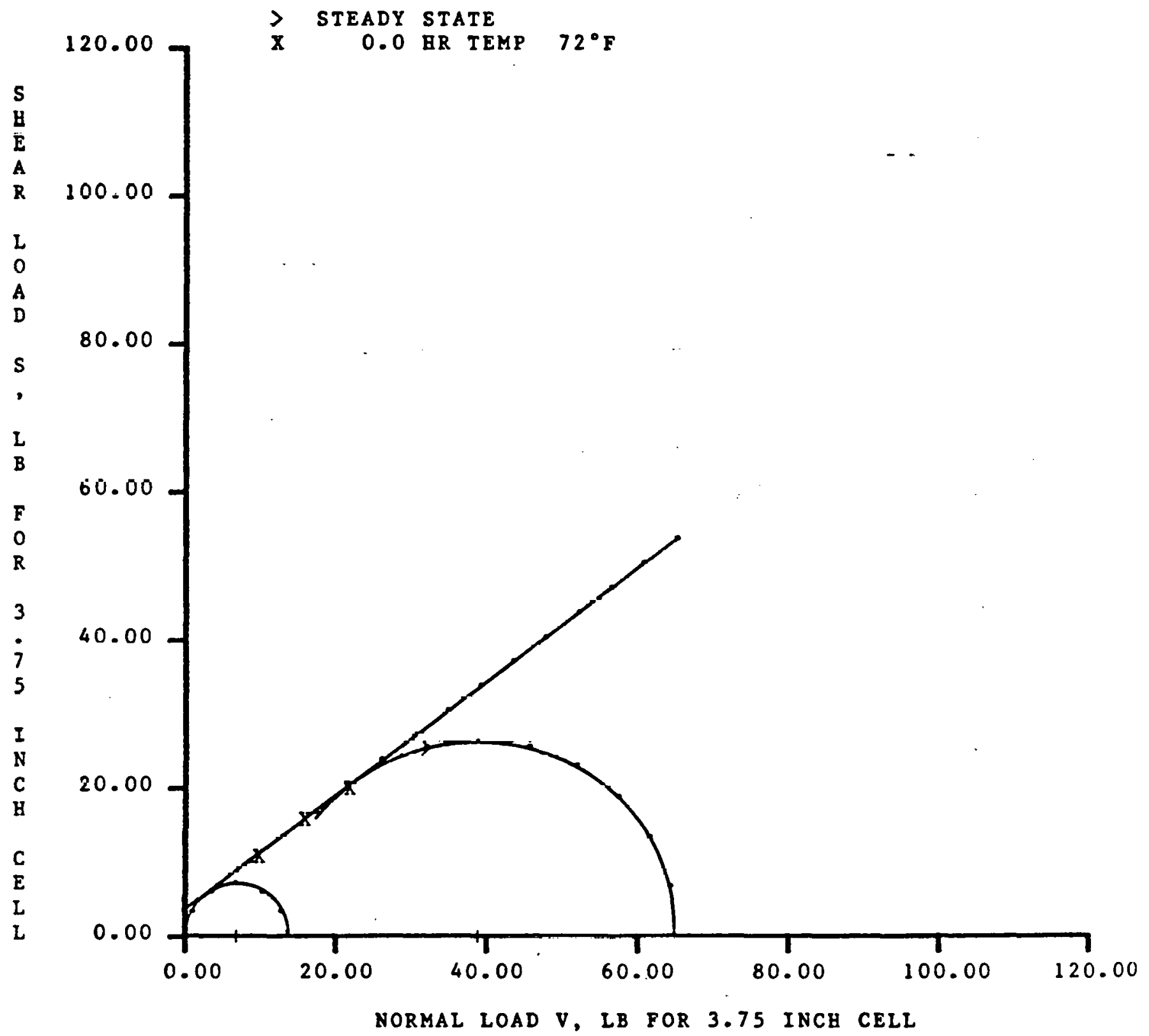


Appendix C 


\section{SELECTION OF BIN AND FEEDER}

\section{Types of Bins}

A bin (silo, bunker) generally consists of a vertical cylinder and a sloping, converging hopper.

In the process of selection of a bin, the first step is to decide on the type of bin required. From the standpoint of flow, ihere are three types: mass flow, funnel flow and expanded flow.

\section{Mass flow bins}

In a mass flow bin, the hopper is sufficiently steep and smooth to cause flow of all the solid without stagnant regions whenever any solid is wi thd rawn.

Mass flow bins, examples of which are shown in Fig. $C l$, have certain advantages. Flow is uniform and the feed density is practically Independent of the head of solid in the bin. This frequently permits the use of volumetric feeders for feed rate control. Since stagnant regions are eliminated, low level indicators work reliably. Even though a solid may segregate at the point of charge into the bin, segregation of the discharge is minimized by the first-in-first-out flow sequence associated with mass flow which enforces the same particle size distribution to exit the hopper as was put into it. This flow sequence also ensures uniform residence time and deaeration of a fine powder.

Mass flow bins are recontended when handling cohesive materials, powders, materials which degrade with time and when segregation needs to be minimized.

Ledges and protrusions are not permitted in a mass flow hopper. In addition the outlet must be fully effective. If the hopper is equipped with a shut-off gate, the gate must not prevent flow of material along the hopper wall. If a feeder is used, it must draw material across the full outlet area. (Sec "Fccders" bclow) 
Mass flow bins can be used for in-bin blending. Some of the limitations of previous designs have recently been overcome with Jenike \& Johanson's patented BINSERT ${ }^{m}$ bin insert. This device controls the flow pattern of solids in a bin.

\section{Funnel flow bins}

Funnel flow occurs when the hopper is not sufficiently steep and smooth to force material to slide along the walls. It also occurs when the outlet of a mass flow bin is not fully effective. Examples of funnel flow bins are shown in Figure C2.

In a funnel flow bin, solld flows toward the outlet through a channel that forms within stagnant material. With a nonfree-flowing solid, this channel expands to a diameter that approximates the largest dimension of the outlet. When the outlet is fully effective, this dimension is its diameter if circular, or the diagonal if $1 t$ is square or rectangular. The channel will be stable if its diameter is less than the critical rathole diameter.

With a free-flowing solid, the flow channel expands at an angle which depends on the effective angle of friction of the material. The resulting flow channel is generally circular with a diameter in excess of the outlet diameter or diagonal.

When the bin discharge rate is greater than the charge rate, the level of solid within the channel drops causing layers to slough off the top of the stagnant mass and fall into the channel. This spasmodic behavior is detrimental with cohesive solids since the falling solid packs on impact, thereby increasing the chance of arching. With sufficient cohesion sloughing may cease, allowing the channel to empty out completely and form a stable rathole. Aerated solid charged into this empty rathole may overflow the feeder.

When a fluidized powder is charged directly into a funnel flow channel at a sutticiently high rate and is withdrawn at the same time, it has no chance to deaerate. It therefore remains fluidized in the channel and flushes when exiting the bin. A rotary valve is often used under these conditions to contain the material, but a uniform flow rate cannot be ensured because flow into the valve is erratic.

In general funnel flow bins are only suitable for coarse, free-flowing or slightly cohesive, nondegrading solids when segregation is unimportant.

Converting funnel flow bins to mass flow can of ten be achieved with relatively little expense. It may be done by using the BINSERT ${ }^{\text {th }}$ referred to in the paragraph on blending above. 


\section{Expanded flow bins}

Examples of expanded flow bins are shown in Figure C3. The lower part of such a bin operates in mass flow while the upper part operates in funnel flow. The mass flow outlet usually requires a smaller feeder than would be the case for a funnel flow bin. The mass flow hopper should expand the flow channel to a diagonal or diameter equal to or greater than the critical rathole diameter. This eliminates the likelihood of ratholing in the funnel flow section.

These bins are used for the storage of large quantities of nondegrading solids. This design is also useful as a modification of existing funnel flow bins to correct erratic flow caused by arching, ratholing or flushing.

The concept can be used with multiple outlets as shown in Fig. C3 (b) where simultaneously flowing mass flow hoppers are placed close enough together to cause a combined flow channel larger than the critical rathole diameter.

With extremely free-flowing solids such as plastic pellets, cement clinker and coarse sand, both funnel flow and expanded flow bins may pulsate. This is caused by the flow pattern suddenly switching from a steady state central channel type flow to a much more extens ive secondary flow pattern that may extend to the bin walls. Such a condition may reduce segregation problems, but the shock loads imposed may seriously challenge the otructural integrity of the hin.

\section{$\underline{\text { Feeders }}$}

The specified outlet must be fully effective. If flow from the bin is controlled by means of a feeder, the feeder must be so designed as to draw uniformly from the entire cross section of the outlet, a condition which not all feeders satisfy.

This uniformity of draw is especially important when feeding fine powders from slotted outlets. Typical commercial designs tend to draw material either from the front or the back of the slot resulting in a high velocity channel having a diameter of one to two times the width of the outlet. The powder may remain fluidized within this channel and flush on exiting the bin.

To limit high initial loads and starting torque caused by differential settlement between the hopper and the feeder, it is essential that the feeder be either suspended from the bin itself or supported on a flexible frame so as to readily deflect with the bin as solid is added to it. When the feeder is properly designed for uniform flow and when convergence of the hopper extends to the feeder, the effective head EH of solid on the 
feeder during flow in a mass flow bin is approximately

$$
\begin{aligned}
& E H=B P \text { for a transition hopper } \\
& E H=B C / 2 \text { for a conical hopper }
\end{aligned}
$$

See page $C 5$ for definitions of $B P$ and $B C$.

Initial loads may be several times these values.

\section{V1braring kquipürent}

Vibration has two effects: while it tends to break arches that obstruct flow, 1t also packs the solid in stagnant regions thereby giving it greater strength. In order to allow for this packing, the recommended outlet dimensions at zero time at rest for a P-FACTOR (described on page C6) of 1.5 may be used as an approximation when calculating critical arching dimensions for use with vibrating equipment.

Vibrators are suftable for materials which are free flowing under conditions of continuous flow but cake and gain strength when stored at rest for hours or days. Hoppers for these materials should be equipped with pads for the wounting of external vibrators. Vibrators should be used only to initiate flow and turned of once flow has started.

Fine powders and wet materials tend to pack severely when vibrated; hence, vibrating equipment is generally not recomended for them. 


\section{DISCUSSION OF TEST REPORT DATA}

In the discussion which follows, each Section of the test report is explained in general terms. Please refer to F1gs. C1, C2, and C3 where many of the symbols are shown. The symbols and other terms used in the text are explained in the Glossary of Terms and Symbols on pages C12 to C15. The concepts of gravity flow of solids and examples of application of colids flow data are presented in greater detall in the attached papers.

\section{Section I - Bin Dimensions for Dependable Flow}

This section specifies the bin outlet dimensions necessary for dependable flow in both mass flow and funnel flow bins. These dimensions have been calculated on the basis of the frictional and cohesive properties of the solid given in a subsequent part of the report. In all cases, it is assumed that flow takes place only under the action of gravity, 1.e. without internal or external assistance.

In general these dimensions are a function of the time the solid remains in storage at rest, its molsture content, temperature, particle size and overpressure, if any, that is applied to it during storage. The P-FACTORs given in the table are ratios of applied compaction pressure to that pressure resulting from gravity flow only. If there are no overpressures present, the critical dimensions for P-FACTOR $=1.0$ should be used. If the $P$-FACTOR is greater than 1.0 , it is assumed that overpressures have been exerted on the solid during storage, but are removed when the solid is required to flow. See page $\mathrm{C} 6$ to $\mathrm{C} 8$.

Mass flow bins have hopper walls which are smooth and steep enough to cause flow along them; hence, stable channels within the material (ratholes) do not develop. Only two dimensions, both of which are shown in Fig. Cl, are specified: $B C$, the minimum outlet diameter for a conical hopper; and $B P$, the minimum width for a slotted or oval outlet. The length of the slot or oval should be at least three times its width or the end walls must be vertical and smooth for BP to apply.

A funnel flow bin is created whenever the hopper walls are not steep and smooth enough to cause flow along them. Slotted outlets are recommended for these bins unless the material is quite free flowing. To prevent stable arches from forming, the width of the slot must be at least equal to BF. In a funnel flow bin the solld is held up at the walls and flows only within a circular channel whose diameter is approximately equal to the diameter or length of the effective outlet. If this flow channel diameter is less than the critlcal rathole diameter DF given in the report, a stable rathole is likely to form and the live capacity of the bin will be 
essentially only that material which is in the flow channel above the outlet. To prevent stable ratholes from forming, funnel flow bins should be designed with slotted outlets of length at least as long as DF.

In general DF is proportional to the consolidating pressure imposed on the solid during filling of the bin. Hence, in the upper regions of a bin where pressures are low, the critical rathole diameter DF 16 small and the flow channel diameter may exceed DF. This causes the rathole to be unstable at this point allowing the material to collapse into the stable rathole below. A partial emptying of the bin will result.

Calculation of Effective Head EH

The critical rathole diameter DF is a function of the major consolidating pressure which acts on the solid in the bin. It is convenient to express this pressure in terms of EH, the effective consolidating head of solid in the bin, as follows:

$$
\text { or } \begin{aligned}
E H & =[R /(\mu k)][1-\operatorname{EXP}(-\mu k H / R)] \\
E H & =2 R
\end{aligned}
$$

whichever is larger. The parameters are

$R=$ hydraulic radius of the cylindrical portion of the bin, 1.e. ratio of cross sectional area to clrcumference.

$R=D / 4$ for a circular cylinder of diameter $D$ or a square cylinder of side $D$.

$R$ - W/ 2 for a long rectangular cylinder of width $W$.

$\mu$ - $\tan$ (FIII-PRIME), cocfficicnt of frietion between the stored fol1 and the cylinder walls (see Section III).

$k=$ ratio of horizontal to vertical solids pressure. $\Lambda$ value of 0.4 is usually acceptable within cylinders.

$\mathrm{H}=$ height of the cylindrical portion of a bin.

\section{Calculation of P-FACTORs}

The magnitude of the overpressure factor can be estimated for vibration, Impact during charging into the bin, external loading, and fluid tlow loading os follows:

VIbration. P-FACTOR $=a_{y} / g \quad$ or $\quad\left(1+a_{x} / g\right)$
whichever is larger, where: 
$a_{x}=$ vertical upward component of acceleration imposed on the solid

$a_{y}=$ horizontal component of acceleration imposed on the solid

$g=$ gravitational acceleration constant

Impact pressure from fall into a bin. A coarse material compacts as it is charged into a bin under the impact of the falling particles. When the material contalns fines and the impact area is close to the outlet, the impact P-FACTOR should be used in the design.

where:

$$
\text { P-FACTOR }=(1+m)[w /(A \text { B GAMMA })] \sqrt{2 h / g}
$$

$w=$ weight flow rate into the bin

$\mathrm{h}=$ height of $\mathrm{fall}$

$m=0$ for a long rectangular outlet

$m=1$ for a circular or square outlet

$A=$ area impacted by the falling stream of solids

$B=$ outlet size or bin dimension in the region of impact, i.e. the diameter in a confcal hopper or the width in a wedge shaped or transition hopper.

GAMMA = bulk density of solid

External loading. If the solid has been compacted by an external load $F$ such as the weight of a tractor passing over an outside stockpile - the overpressure factor at the point of application is given by

where:

$$
\text { P-FACTOR }=(1+m) F /(\text { A B GAMA })
$$

$A=$ area of load application.

Liquid or gas flow loading. If the solid has been subjected during storage to fluid or gas flow such as may have been imposed by an air blaster, draining of a saturated solid or the flow of alr or gas during drying or chemical processing, the overpressure factor is given by

$$
\text { P-FACTOR }=1+(d p / d x) /(\text { GAMMA })
$$

where:

$d p / d x=$ the downward (vertical) liquid or gas pressure gradient at the bin outlet.

In any of the above cases, if the overpressure continues to act during the discharge of the solid and is positive downward, the overpressure factor need not be applied. If the downward pressure acts only during discharge, the dimensions given in Section I A for P-FACTOR $=1.0$ may be reduced by dividing them by the appropriate P-FACTOR.

When considering the effect of overpressure which acts on a solid during 
time of storage at rest, it is not necessary that the overpressure act during the entire time at rest. Soon after an overpressure has been applied, a solid reaches the maximum densification associated with that overpressure. Hence, the critical outlet dimensions will be essentially the same whether the overpressure acts for a short time or contimously during the entire time at rest.

\section{Limits on Bin Sizes}

The bin dimensions in part $A$ of this Section I apply to bins of unlimited maximum size. However, some materials wlll compact in large bins causing large stable arches in the upper part of the hopper whlle the lower portion may discharge without a problem. Th1s can lead to a very dangerous condition when a large arch is broken high in the hopper. The impact of the falling material may cause structural damage to the bin and possibly tear the hopper from the vertical bin section. If the material is capable of this type of behavior, an additional part $B$ is included which gives the maximum allowable mass flow bin and hopper dimensions.

Often the upper limits on bin slze occur only for compaction with time or for significant overpressure conditions. If this is the case, the bin can be designed for an unlimited size provided the critical time and overpressure values are not exceeded during the bin operation.

\section{Section II Bulk Density}

The bulk density GAMMA of a material is used in bin load and capacity calculations. Values of bulk density of the sample tested are given in Section II as a function of the effective head of solid EH and the major principal consolidating pressure SIGMAl. The relationship is:

$$
\text { SIGMAI = EH } \times \text { GAMMA }
$$

Within the cylindrical part of a bin, the effective consolidating head EH is given by eq.(2). At the outlet of a mass flow bin, the head is given by eq. (1).

Note that if the sample tested is the fine fraction of a material having a wide range of particle size, inclusion of the coarser particles will usually increase the bulk densities above those given in this section.

Bulk density values have been computed from measured compressibility parameters of the material which are also given in Section II. In general, 
all materlals have a minimum density GAMMA MINMMM wh thout fluidization. The relationship between bulk density and consolidating pressure only applies when densities are greater than GAMA MINIMUM.

\section{Section III Maximum Hopper Angles for Mass-Flow}

A solid sliding on a bin wall encounters frictional resistance proportional to the tangent of the wall friction angle PHI-PRIME. This angle generally depends not only on the roughness of the wall but also on the pressure which the solid exerts on the wall. For hard wall surfaces, the friction angle decreases as the solids contact pressure increases. This pressure, which varies with position in the bin, is usually smallest at the outlet.

THETA-C and THETA-P are the recommended maximum hopper wall angles, measured from the vertical, for conical and transition mass flow hoppers, respectively. See Fig. C1. These values have been calculated from the friction tests (wall yield loci) included at the end of the report and are tabulated for a serles of widths of oval hoppers and diameters of conical hoppers.

To minimize headroom consider changing the slope of the hopper wall as a function of position. For example, if a conical hopper is to be designed with an outlet dlameter of $1 \mathrm{ft}$ and the recommended THETA-C is $14^{\circ}$ at $1 \mathrm{ft}$ diameter and $23^{\circ}$ at $2 \mathrm{ft}$ and larger diameters, use two confcal sections. In the lower section where the diameter varies from $1 \mathrm{ft}$ to $2 \mathrm{ft}$, use a hopper angle of $14^{\circ}$. Above the $2 \mathrm{ft}$ diameter, use a hopper angle of $23^{\circ}$.

Often, both continuous flow and time friction tests are run on a material. If the solid adheres to the wall with time, the time test results will indicate an increase in friction angles. To overcome this time effect, the hopper walls should be made steeper, as recommended, or other means - such as vibration of the bin walls - should be provided to initiate flow.

\section{Section IV Critical Solids Flow Rate}

The maximum rate $Q$ at wh1ch a coarse solid (say, $95 \%$ plus $1 / 4$ inch) flows out of a mass flow hopfer is practically independent of the head of solid and is approximately given by

$$
Q=(A \text { GAMMA }) \sqrt{B g /(2(1+m) \tan (\text { THETA })]}
$$

where:
$A=$ area of the outlet.
$B=$ diameter or width of the outlet. 


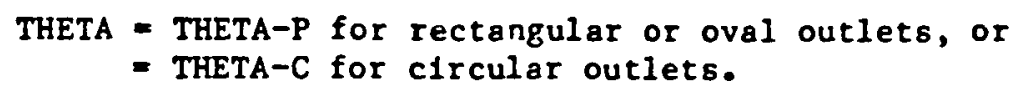

Predicting the flow rate of fine solids is more complicated because their outflow rate is critically affected by.the amount of alr entrained in the sol1d.

Two limiting cases may occur: first, the bin may be charged and discharged at such a rapid rate that a large amount of alt le cntrained within the solid. As a result the solid may flush and flow uncontrollably from the outlet independent of feeder speeds. The prediotion of this illllcal tlushing condition requites an extensive two-phaoc flow calculaiton using a Jenike Johanson proprietary computer program and is not a part of this Standard Test Report.

Second, the bin may be filled intermittently with sufficient retention time before discharging to deaerate the solid. As a result there may be a deficiency of alr as the solids expand upon discharging. This generally causes a critical flow rate at the outlet which is tabulated in this section as a function of effective head of solid in the bin. Above this critical rate, flow will be nonsteady.

The critical rates are computed on the assumption that there is no air in-flow or out-flow along the height of the bin, that air pressure at the outlet of the bin is the same as at the top of the bin, and that the feeder outlet is not sealed against air in-flow. Should the operating rnnitions dcviate frum lliese assumptions, a controlled rate different from the critical may be possible.

If the cabulated flow rates are smaller than desired, it may he neccosary Lu: ust dil alr permeation system to increase the rate; increase the outlet size; decrease the bin size; or limit the storage time to prevent deaeration of the solid. Jenike \& Johanson can analyze the system and make recommendations.

If the specified flow rate from a bin is close to critical values, it is particularly important that the feeder withdraw uniformly across the entire outlet. If this is not done, localized limiting rate effects may occur at the outlet, especlally at the ends of a slotted outlet. This may result in pulsating flow from the bin, the development of fast flowing columns and an uncontrolled rate of withdrawal with flushing.

All the above comments apply as well when a gas other than air is used in the bin. The critical property is the viscosity of the gas. The permeability tests run by Jenike \& Johanson are done with alr at room temperature. When the gas or the temperature is different, the coefficient 
of permeability needs to be modified, as discussed below.

\section{Section V Alr Permeability Test Results}

Values of air permeability are expressed as a function of the bulk density of the solid. These values are used in the calculation of critical flow rates, given in Section IV, and in the design of air permeation systems.

The equation given in this section and the test method are both based on the assumption of laminar flow of gas. This assumption is generally valid for all powders and for most materials which have a significant portion of particles less than 20 mesh in size.

The permeability factor $K$ has the dimension of velocity and 15 inversely proportional to the viscosity of the gas. The results can be adjusted to elevated temperatures and to other. gases by multiplying the constant $K O$ by the ratio of the viscosity of air at room temperature to that of the gas at the temperature in question. 


\section{GLOSSARY OF TERMS AND SYMBOLS}

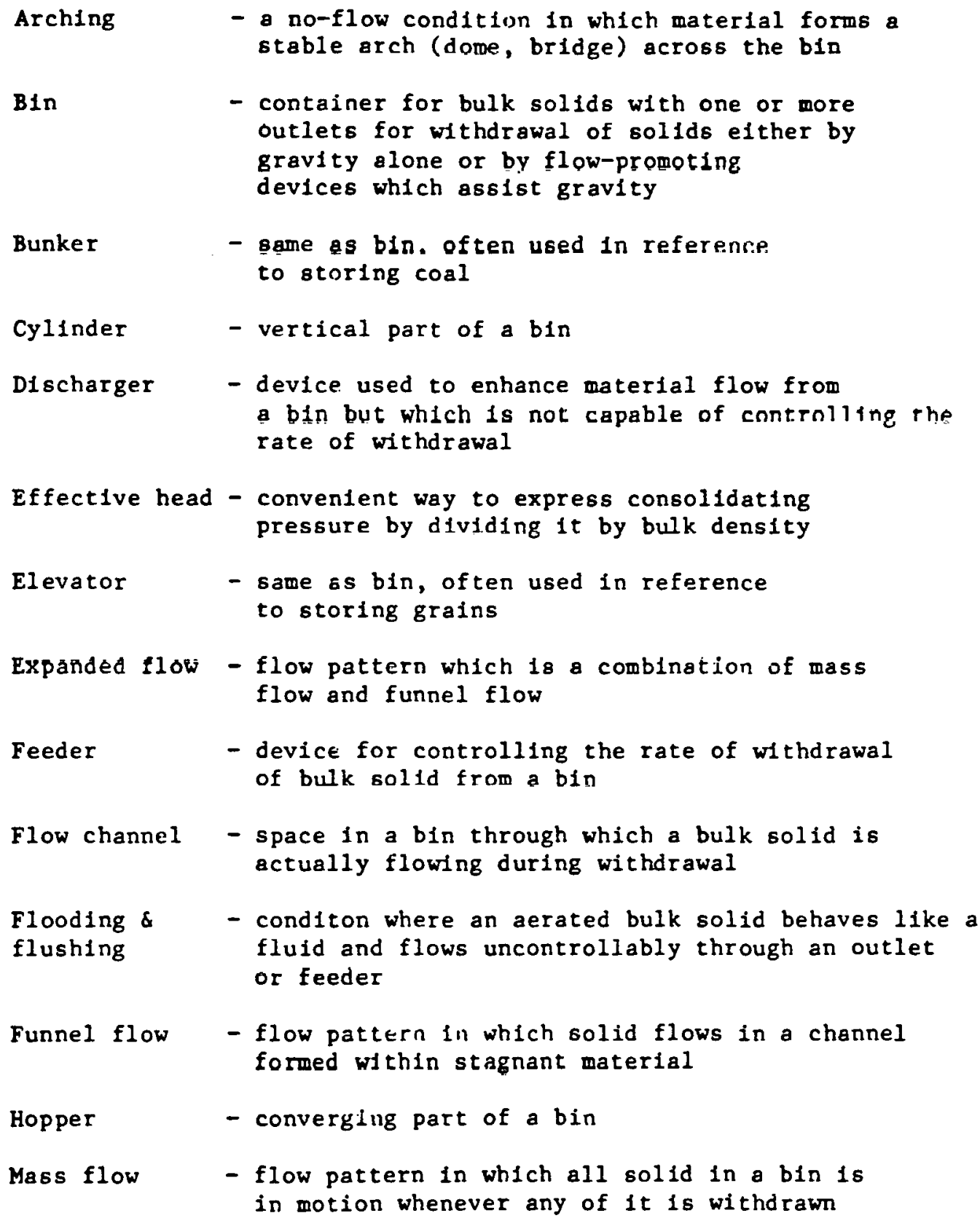

Hopper

- converging part of a bin

Mass flow

- flow pattern in which all solid in a bin is in motion whenever any of $1 t$ is withdrawn 


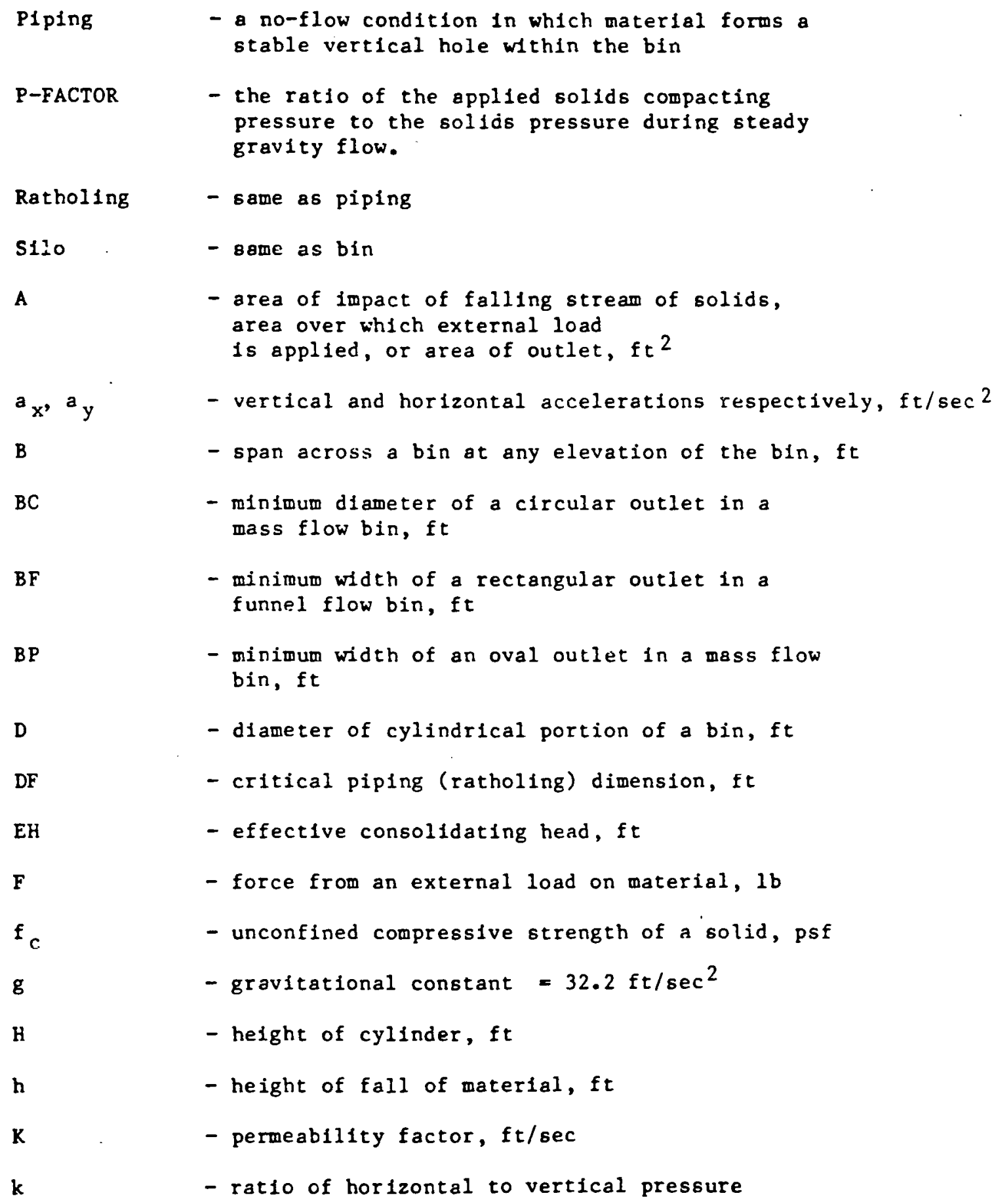

- vertical and horizontal accelerations respectively, ft/sec 2

- span across a bin at any elevation of the bin, ft

- minimum diameter of a circular outlet in a mass flow bin, ft

- minimum width of a rectangular outlet in a funnel flow bin, ft

- minimum width of an oval outlet in a mass flow bin, ft

- diameter of cylindrical portion of a bin, ft

- critical piplng (ratholing) dimension, ft

- effective consolidating head, ft

- force from an external load on material, lb

- unconfined compressive strength of a solid, psf

- gravitational constant $=32.2 \mathrm{ft} / \mathrm{sec}^{2}$

- height of cylinder, ft

- height of fall of material, ft

- permeability factor, ft/sec

- ratio of horizontal to vertical pressure 


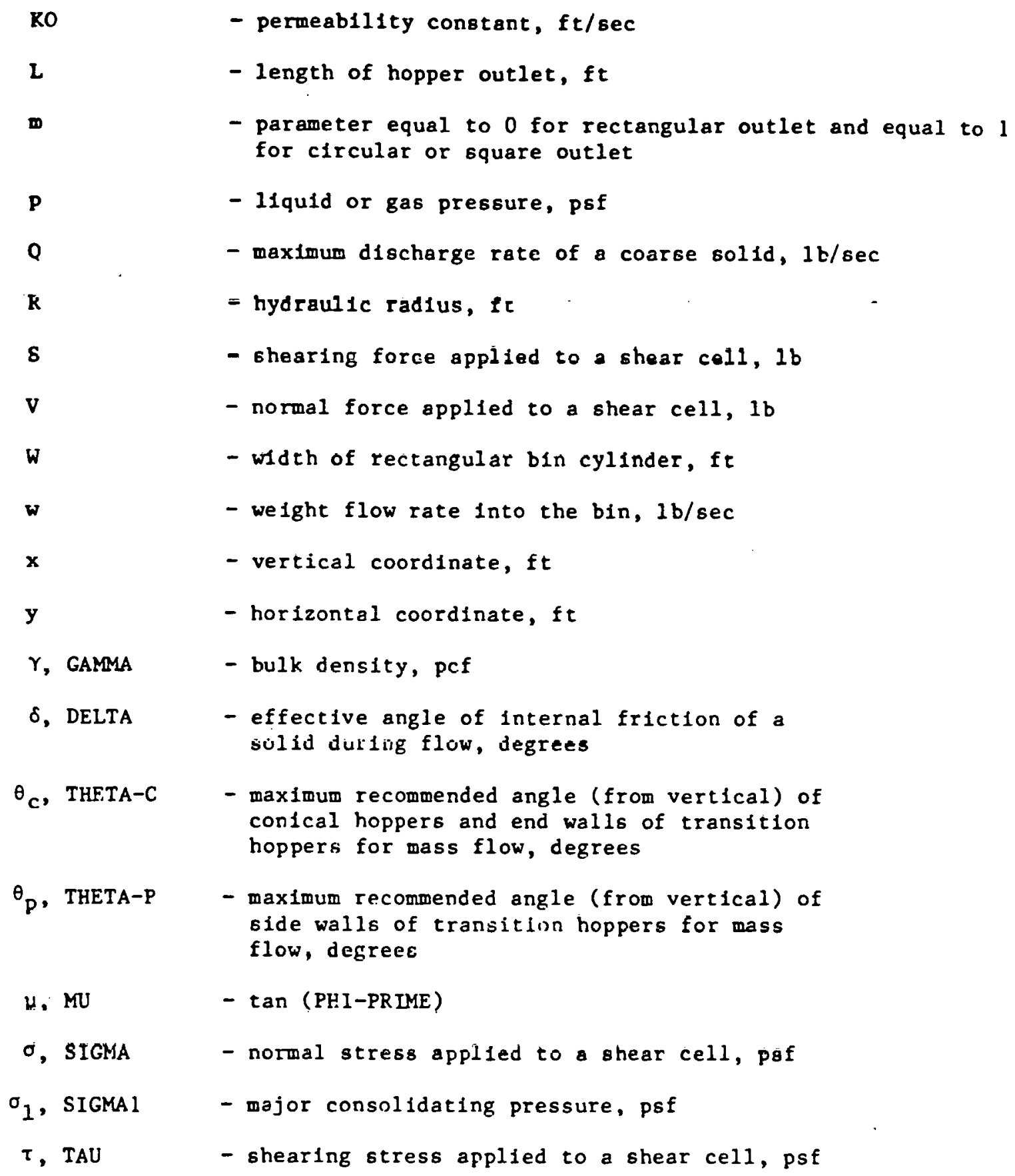

L

m

p

Q

K

8

v

w

w

$\mathbf{x}$

y

$\gamma$, GAMMA

$\delta$, DELTA

$\theta_{c}$, THETA-C

$\theta_{p}$, THETA-P

น. MU

$\sigma$, SIGMA

$\sigma_{1}$, SIGMA I

T, TAU

- length of hopper outlet, ft

- parameter equal to 0 for rectangular outlet and equal to 1 for circular or square outlet

- 11quid or gas pressure, psf

- maximum discharge rate of a coarse solid, $1 \mathrm{~b} / \mathrm{sec}$

= hydraulic radius, ic

- shearing force appilied to a shear cell, 1b

- normal force applied to a shear cell, ib

- width of rectangular bin cylinder, ft

- weight flow rate Into the bin, $1 \mathrm{~b} / \mathrm{sec}$

- vertical coordinate, ft

- horizontal coordinate, ft

- bulk density, pcf

- effective angle of internal friction of a sulid durling flow, degrees

- maximum recommended angle (from vertical) of conical hoppers and end walls of transition hoppers for mass flow, degrees

- maximum recommended angle (from vertical) of side walls of transition hoppers for mass flow, degreeE

- $\tan$ (PHI-PRIME)

- normal stress applied to shear cell, pof

- major consolidating pressure, psf

- shearling stress applied to a shear cell, psf 
$\begin{aligned} \phi^{\prime}, \text { PHI-PRIME - kinematic angle of friction between a solid } & \text { and a wall, degrees }\end{aligned}$

$\phi$, PHI - angle of internal friction of a solid in inclplent flow, degrees 


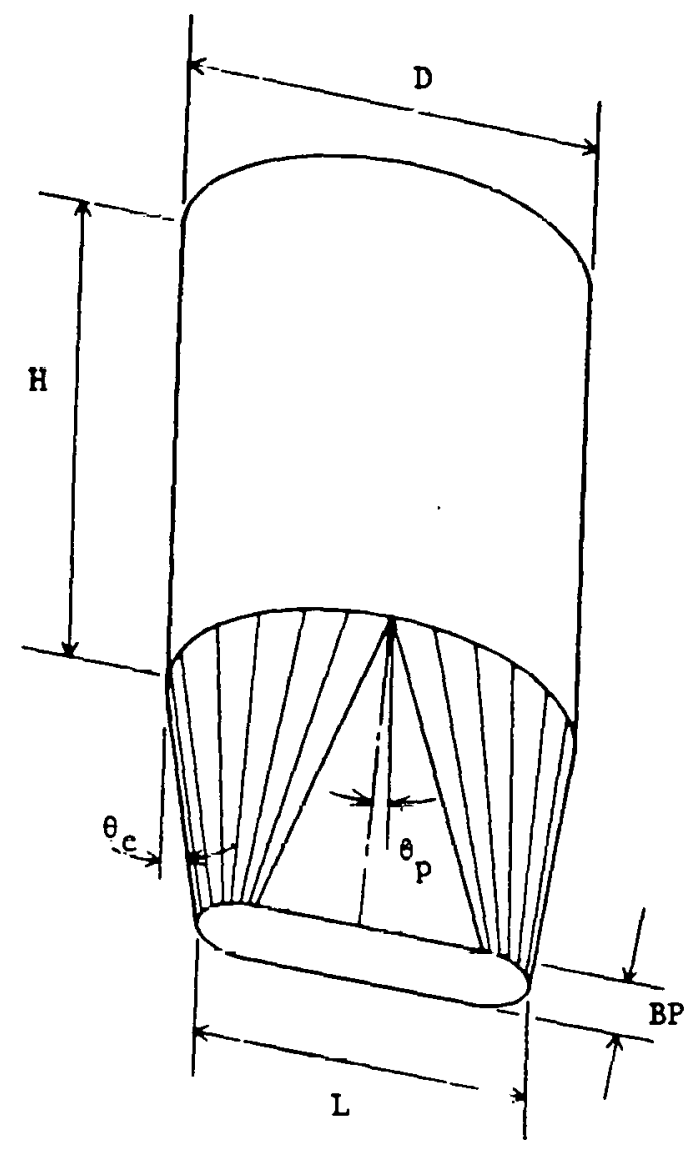

Transition Hopper

(a)

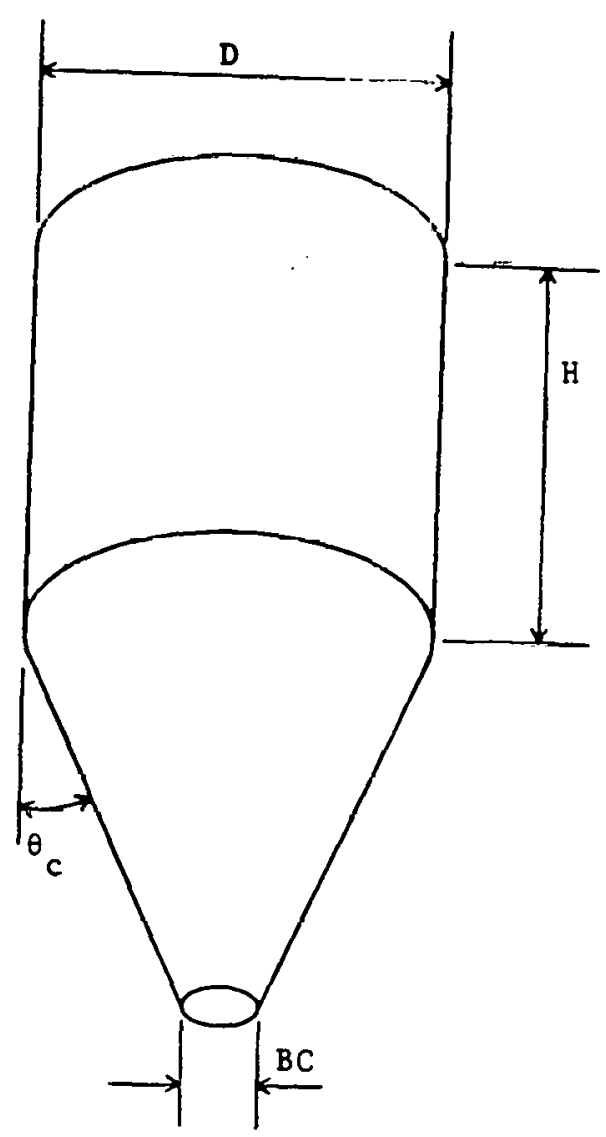

Conical Hopper

(b)

MASS-FLOW BINS

FIG. C1 


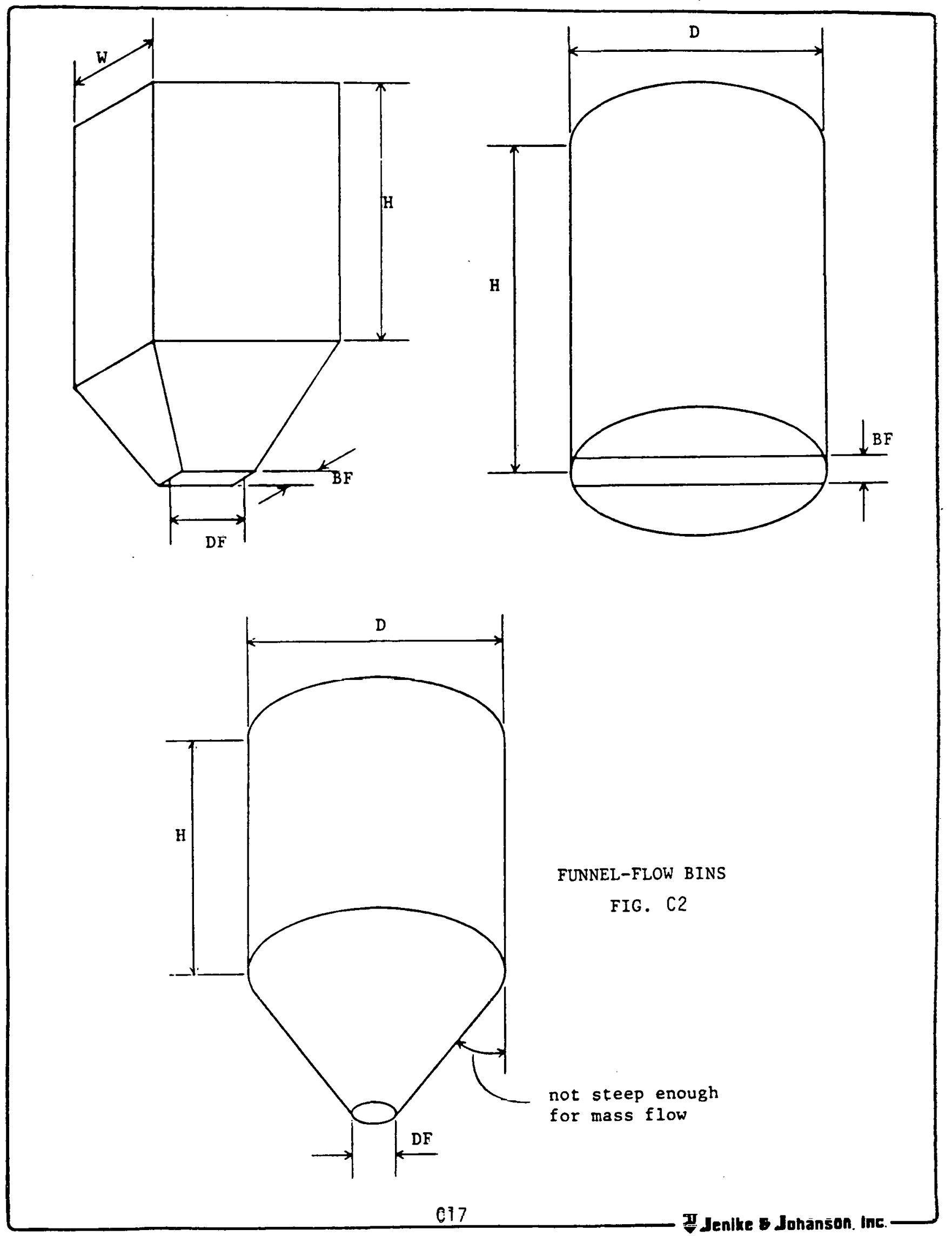




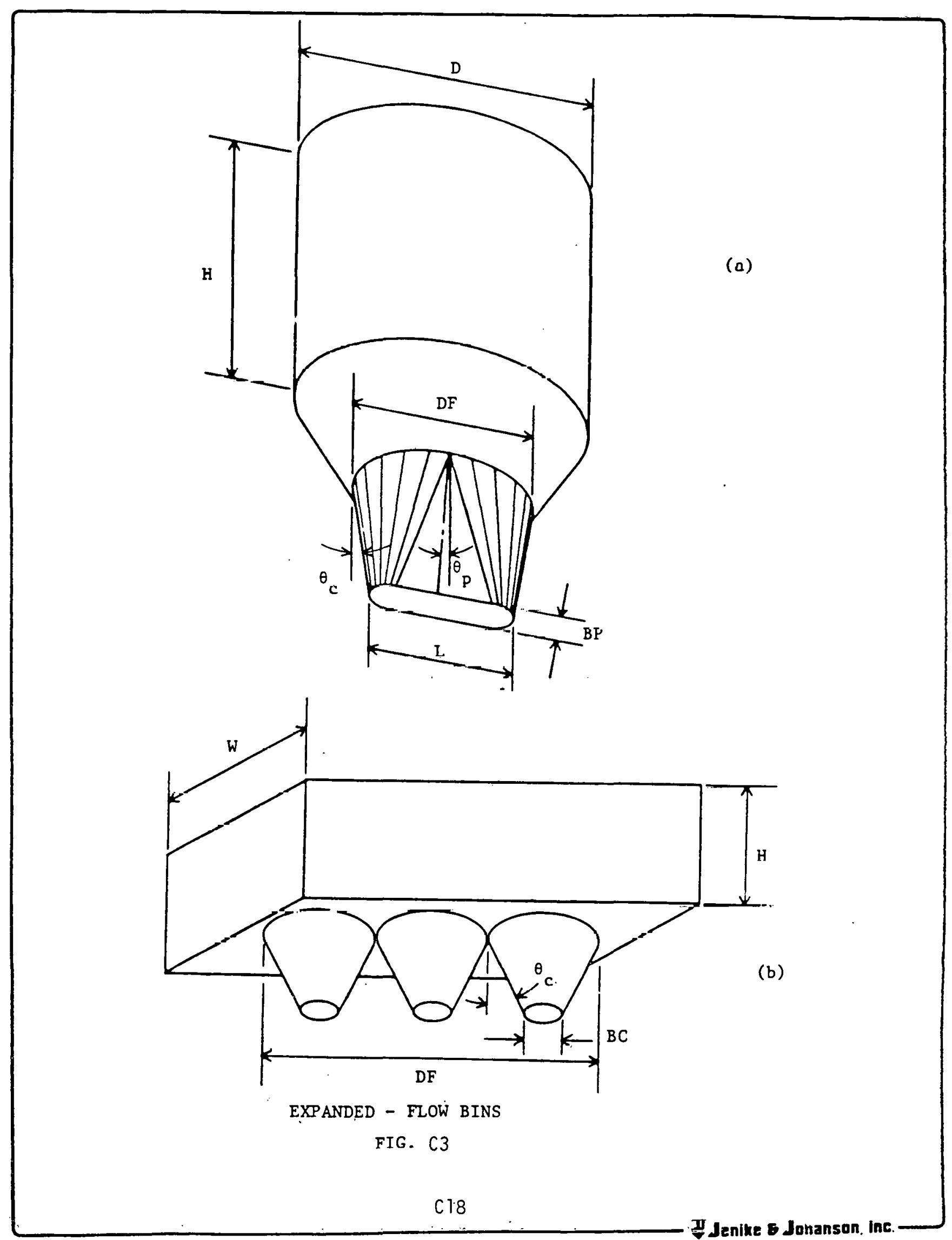




\section{Appendix D}




\section{RECOMMENDATIONS FOR FUTURE WORK}

The purpose of this report is to establish whether Kerr-McGee Ash Concentrate (KMAC) can be fed to the Gesellschaft für Kohle-Technologies (GKT) gasifier using a storage bin and screw feeder system designed by GKT to handle coal.

It was known from GKT's experience that a given screw feeder gives unsatisfactory performance outside the ranges of certain critical feed property parameters. The investigation was to estimate the ranges of similar parameters for the various KMACs and to predict the performance of the GKT-Designed system.

As a result of the review of this report completed by the Department of Energy (DOE), the following items are recommended for future work.

\section{FEED PROPERTY PARAMETERS}

In general, it appears that the systems currently in operation handling coal are sensitive to slight changes in coal flow properties, but that the coals being handled have fairly consistent flow properties, even with the addition of water. The KMACs tested seem to have a much wider variation of properties from lot to lot than the coal; consequently, JJI expects more problems achieving a suitable system design to lididle the range of KMACs tcsted than to handle the conals. More feed materials, especially KMAC samples, should be tested in a similar manner in order to add to the parameter data base established in this report. In particular, better definition of both spitting flow and plugging problems needs to be determined. The limits for these important parameters need to be determined experimentally and proven on larger scale tests.

\section{FLOW RATES}

It appears that any system designed for coal will not work for the typical KMAC feeds unless a significant reduction in throughput (feed 
rate to the gasifier) is used. It is possible to design a system to handle the KMAC at the required rates of about 5.3 to $7.6 \mathrm{tph}$. Such a system would likely require a larger surge hopper to deaerate the KMAC and larger screws turning at a lower rpm than those currently used for coal at $5.6 \mathrm{tph}$. The design parameters of the system could be established by use of JJI's two-phase-flow computer program.

\section{SYSIEM DESIGN}

Based on the present and any future developed data, the feed system should be designed for the Demonstration Plant Gasification Unit. The surge hoppers should be adequately sized and specified as to flow mode. In order to achieve normal operation and/or required flexibility, it may be necessary to install dedicated feeders for coal and KMAC rather than a single system designed to feed coal and coal/KMAC mixtures.

\section{DESIGN VERIFICATION}

A listing and brief details of previous JJI's materials testing and modelling techniques which were successfully demonstrated in commercial applications would prove beneficial for the design of the SRC-I Demonstration Plant. 
